\title{
An Employment Systems Approach to Turnover: HR Practices, Quits, Dismissals, and Performance
}

May 2011

ROSEMARY BATT

rb41@cornell.edu

and

ALEXANDER J. S. COLVIN

ajc22@cornell.edu*

*The authors are listed alphabetically to reflect equal contribution to authorship. Rosemary Batt is the Alice H. Cook Professor of Women and Work, and Alexander J.S. Colvin is associate professor, both at Cornell University. The research is based on a multi-year study of call center operations conducted in collaboration with Harry C. Katz and Jeffrey Keefe and generously funded by the Alfred P. Sloan Foundation.

Copies of the computer programs used to generate the results in the paper may be obtained from the authors at the Industrial and Labor Relations School at Cornell University, Ithaca, NY 14853-3901, 607254-8206 (ph), ajc22@)cornell.edu. 


\title{
AN EMPLOYMENT SYSTEMS APPROACH TO TURNOVER: HR PRACTICES, QUITS, DISMISSALS, AND PERFORMANCE
}

\begin{abstract}
This study examines the relationship between alternative approaches to employment systems and quits, dismissals and customer service, based on cross-sectional and longitudinal data from nationally representative surveys of call center establishments. Contrary to prior literature, the antecedents and consequences of quits and dismissals are quite similar. Comparing three dimensions of employment systems, we find that high imvolvement work organization and long-term investments and inducements are associated with significantly lower quit and dismissal rates, while short term performance-enhancing expectations are related to significantly higher quit and dismissal rates. Establishments with higher quit and dismissal rates have significantly lower customer service, as reported by managers.
\end{abstract}




\section{INTRODUCTION}

Turnover is among the most important employment relations outcomes for both employees and organizations. Employees face the uncertainties of job search and potential unemployment. Organizations confront uncertain costs and benefits: The costs of operational disruption and replacement of human capital versus the benefits of lower-cost labor, or fresh skills to compete on innovation. These uncertainties raise the question of which management practices increase turnover; how much turnover is harmful or beneficial, and under what conditions and why? These questions have spawned a small, but growing set of organization level studies of the antecedents and consequences of turnover. This research complements the large micro-organizational literature on how and why individuals choose to quit their jobs (Griffeth, Hom, \& Gaertner, 2000; Hom \& Griffeth, 1995; Maertz \& Campion 2004).

However, research has largely focused on the issue of voluntary turnover, or total turnover more generally, neglecting involuntary turnover in the form of dismissals. Here, we define dismissals as employer decisions to fire individual employees, rather than decisions to cut costs through mass layoffs, downsizing, early retirement buyouts, or organizational restructuring. The few existing studies of dismissals have conceptualized them as distinct from quits, with different antecedents and consequences (Dalton \& Todor 1979; Donaghue \& Castle, 2006; Knight \& Latreille, 2000; Shaw et al. 1998). While dismissals are viewed as the result of hiring errors, which employers may correct by terminating poor performers, quits are seen as a relatively rational process in which employees weigh their current job against alternative prospects. The literature often assumes that quits undermine performance because better performers are more likely to quit than poor performers, but theory and evidence are equivocal (McEvoy \& Cascio, 1987; Osterman, 1987; Trevor, Gerhart, \& Boudreau, 1997). 
This paper draws on an alternative perspective, internal labor market theory (Doeringer \& Piore 1971; Osterman, 1987), which focuses on how employers establish sets of internal administrative rules (e.g., HR practices or employment systems) to advance their goals. Here, quits and dismissals are viewed as related phenomena with similar antecedents deriving from the type of employment system that employers choose. Employers may manage turnover levels via their choice of HR practices; and the optimal turnover level may vary by market, industry conditions (Abelson \& Baysinger, 1984), business strategy, or values (Baron, Burton, \& Hannan, 1996). Cost-focused firms, for example, may use high turnover to minimize labor costs. Jack Welch at GE, by contrast, built a 'performance culture' through an explicit policy of dismissing 10 percent of employees each year (Welch, 2005: 37-52).

To investigate these alternative theories, we examine the relationship between quits and dismissals and three dimensions of the employment system: work organization, commitmentinducing long term incentives, and performance-enhancing short-term incentives. We also explore their relationship to customer satisfaction, an increasingly important outcome for firm competitiveness (Fornell, Van Amburg, Morgeson, \& Bryant, 2005; Lovelock \& Wirtz, 2005). We draw on a 2003 national survey of US call centers, as well as longitudinal data for a subset of these establishments. Call centers are an appropriate context for this study because high rates of turnover are a major source of high costs and poor service quality. Despite off-shoring trends, they also employ over 4 million workers in interactive voice services ( 3 percent of the US workforce), compared to less than 400,000 comparable employees in India and the Philippines (Batt, Holman, \& Holtgrewe, 2009: 465). 


\section{THEORY AND HYPOTHESES}

The theory that quits and dismissals have distinct antecedents draws on the early work of Dalton and others, who distinguished between 'functional' turnover (where poor performers leave) and 'dysfunctional' turnover (where high performers leave) (Dalton, Krackhardt, \& Porter 1981; Abelson \& Baysinger, 1984). Dismissals are equated with functional turnover while quits are equated with dysfunctional turnover (Jacofsky, 1984; Sturman, Trevor, Boudreau, \& Gerhart, 2003). McElroy and colleagues, for example, argued that, "Dismissals are a function of poor individual performance or of insubordination...." (2001:1294). Shaw and colleagues noted that, "In an organization with high quit rates, for various reasons employees find it more attractive to leave than to stay. In an organization with high discharge rates, however, presumably incorrect hiring decisions are remedied through termination" (1998:512). Of course, poor performance also may be due to other factors than hiring errors - new production systems may render employee skills obsolete, employee motivation or commitment may change.

The assumption that quits and dismissals have distinct antecedents is theoretically plausible, but has not been systematically tested, and existing studies show mixed results Wanous, Stumpf, and Bedrosian (1979) found that job attitudes and performance were significant predictors of both types of turnover, but job attitudes explained more variance for quits, and performance more variance for dismissals. Organizational factors (job training and pay) accounted for the most variance for both types of turnover. Stumpf and Dawley (1981) found that absenteeism and job performance significantly explained the incidence of both quits and dismissals, but absenteeism explained a higher proportion of variance in dismissals.

Recent organization-level research also provides mixed results based on industry-specific studies of trucking (Shaw et al. 1998) and nursing homes (Donaghue \& Castle, 2006). Donaghue 
and Castle (2006) found several differences between quits and dismissals, but noted that “... most of the organizational characteristics held similar associations to voluntary and involuntary turnover..." (2006:467). Shaw and colleagues (1998) argued that commitment-enhancing investments and inducements (higher pay, benefits, job stability, training) should lower quit rates, while performance-enhancing HR practices (electronic monitoring, longer work hours) that raise the expectations of employee effort and accountability should increase quits. By contrast, a third HR practice -- the staffing system (selection procedures, performance appraisals) -- should only affect dismissals. While some of their predictions were confirmed, the paper raised other questions. Why should performance-enhancing practices only affect quit rates, when these practices should uncover weaknesses in poor performers, leading to their dismissal? Similarly, why should better selection procedures only affect dismissals, when quit rates depend on getting the right 'fit' between the individual and the organization?

Existing research, therefore, leaves many questions unanswered and suggests that other theories may help explain these relationships. Osterman, for example, argued that employers view turnover "... as a strategic variable - part of a larger set of personnel policies that the firm manipulates to achieve its ends... In some models, the firm ... explicitly considers and chooses the level of turnover along with other characteristics of the employment system" (1987: 289-90). Firms that choose to compete on service quality or customer loyalty may seek to keep turnover low, as research suggests that quality is higher where turnover is lower - due to employee motivation (Schlesinger \& Heskitt, 1991) or to the firm-specific skills and knowledge of customers that experienced workers have (Batt, 2002). By contrast, a high turnover model may be acceptable or even desirable for cost-focused firms if lower operational costs outweigh higher turnover costs. In his classic defense of the production-line approach to services, Levitt (1972) 
argued that efficiency and profitability would be higher if service industries adopted more standardized work processes - processes that also create more monotonous, high turnover jobs (Schlesinger and Heskitt, 1991). Of course, not all firms think strategically about turnover; and many, particularly those facing weak competitive markets, may use 'bad' or unproductive management practices (Bloom \& Van Reenen, 2007), which are likely to result in high turnover.

In the sections below, we examine specific HR practices, and their theoretical relationship to quits, dismissals, and operational performance. Theory is more well-developed for quits than for dismissals (Griffeth, Hom, \& Gaertner, 2000; Hom \& Griffeth, 1995; Maertz \& Campion 2004). Employees quit when they are dissatisfied with HR practices and working conditions; and their quitting raises labor costs and disrupts operations. Employees are dismissed, by contrast, when HR policies allow employers to identify weak performers or lead employees to perform badly, ultimately leading to their dismissal. This may occur in two ways. Some HR practices, such as performance monitoring, provide information that allows poor performers to be more accurately identified and dismissed. Other HR practices create more demanding or onerous work, leaving the less-able more exposed to discipline, and ultimately dismissal.

We analyze three sets of HR practices, rather than HR practices taken as a coherent bundle, because prior research suggests that they have potentially different effects (Appelbaum, Bailey, Berg \& Kalleberg, 2000; Batt et al., 2002; Shaw et al., 1998, 2009). Building on the work of Shaw and colleagues $(1998,2009)$, we examine investments and inducements (practices that invest in employees' human capital and induce commitment), and performance-enhancing expectations (practices that enhance performance expectations). We also examine the role of work organization because considerable research has demonstrated its substantial relationship to turnover and performance (Appelbaum et al., 2000; Batt, 2002; Wood et al., 2006) 


\section{Work Organization}

Variation in work organization has grown in recent decades as employers have used different approaches to compete on price, quality, innovation, or time-to-market. Some organizations rely on Taylorized work design (individually-defined jobs with low discretion), characteristic of mass production systems, while others have promoted employee involvement and group problem-solving and learning. The large job characteristics literature provides persuasive evidence that Taylorized jobs demotivate workers and lead to higher turnover (Dalton \& Todor, 1979); while higher discretion jobs are more intrinsically meaningful (Hackman \& Oldham, 1980), leading to higher satisfaction, commitment, and lower quits (Wood et al., 2006). Approaches to work design that combine employee discretion with group problemsolving are often defined as 'high involvement work organization'. Drawing on concepts from total quality management (TQM) (Deming, 1982) and socio-technical systems (STS) (Trist, 1981), this approach assumes that employees need discretion at work in order to utilize their tacit knowledge to diagnose and solve operational problems. These literatures also assume that problem-solving is best achieved through group collaboration: Under TQM, quality circles that discuss problems 'off-line' (away from work stations); and under STS, work organized into 'online' teams, with considerable operational autonomy

Although some argue that team-based systems are potentially onerous because peer monitoring and enforcement of group norms may dominate individual discretion (Barker, 1999), even in Barker's classic ethnography of self-managed teams, employees preferred teams over the prior system of Taylorized work. In settings such as call centers, where work tasks are individualized and scripted, opportunities for greater discretion and group interaction have been 
found to relieve boredom, stress, and social isolation, leading to lower absenteeism and turnover and better sales performance (Batt, 1999, 2002; Deery, Iverson, \& Walsh, 2002).

While theory and evidence provide reasonable support that high involvement work design reduces quit rates (Arthur, 1994; Batt, 2002; Huselid, 1995), the predictions for dismissals are less clear. Dismissals may be higher than in Taylorized operations if those employees who have fewer skills or abilities are given more discretion, and they stand out as unable to perform; or if peer-monitoring exposes free-riders, leading to their discipline or dismissal (Barker, 1999). However, we believe that dismissals are likely to be higher in Taylorized systems because individual performance may be more accurately monitored and poor performers cannot free ride in their workgroups. In addition, high involvement systems provide a structure of cooperation and mutual learning in which employees who run into problems can obtain help from coworkers. In sum, high involvement work organization may 'raise all boats' and lower dismissals.

A less generous argument yields a similar hypothesis. Where workers have greater control over the work process, as in high involvement work systems, they can sanction managers who engage in what they view as unjustified disciplinary action (Klaas, Brown \& Heneman, 1998) yielding lower dismissal rates. In sum, the existing literature yields the following hypothesis:

Hypothesis 1: Work organization practices that enhance employee discretion and group collaboration will be associated with lower quit rates and lower dismissal rates.

\section{Long-term Incentives: Investment and Inducement Strategies}

The concept of investments and inducements draws on internal labor market theory which posits that higher relative pay, benefits, internal promotion opportunities, and procedures for employment security provide long-term incentives that lead employees to stay with the organization (Doeringer \& Piore, 1971). Employers may seek low voluntary turnover to compete 
on the basis of firm-specific skills or a unique human resource base. The empirical evidence of a negative relationship between investments and inducements and voluntary turnover is growing, including organizational studies that measure bundles of high involvement work and commitment-enhancing practices (Arthur 1994; Huselid 1995), as well as those with separate measures of inducements and investments (Batt et al., 2002; Shaw et al., 1998).

However, the theoretical relationship between these long-term incentives and dismissals is undeveloped. Dismissals may be higher in these systems if employers are unwilling to make costly investments in employees whom they perceive as less able to perform or to learn new tasks. However, we believe that these incentives are more likely to motivate employees to avoid the types of behaviors that lead to dismissal. According to efficiency-wage theory, employees of firms paying above market wages should engage in less shirking, thereby reducing disciplinary problems that lead to dismissal (Cappelli \& Chauvin, 1991; Klaas, Brown \& Heneman, 1998). Generous benefit packages and internal career ladders should similarly engender this effect. Firms that invest more in the workforce may be reluctant to dismiss workers with this accumulated human capital (Klaas, Brown \& Heneman, 1998), unless the employee misbehavior is egregious. The unfolding model of turnover also suggests that employee development plays the role of maintaining skills and reducing the likelihood of precipitating events that lead to an employee's leaving a job (Lee \& Mitchell, 1994). Finally, employers who attempt to compete by building a culture of trust and the synergies of social capital (Leana \& Van Buren III, 1999) may try to limit overall turnover as much as possible because it disrupts the social fabric of work.

Empirical support for these arguments is mixed. Shaw and colleagues (2009) found that HRM inducements were negatively related to the quits of both 'good' and 'poor' performing employees, significant for the former in study 1 and the latter in study 2 . Knight and Latrielle 
(2000) argued that high commitment practices should be associated with lower dismissal rates, but they only found a negative relationship between dismissals and profit-sharing. In sum, the bulk of existing theory and evidence suggest that inducements and incentives should have the same relationship to quits and dismissals:

Hypothesis 2: Employment practices emphasizing inducements and investments will be associated with lower quit rates and lower dismissal rates.

\section{Short-term Incentives: Performance-enhancing Expectations}

The concept of performance-enhancing expectations (Shaw et al., 1998; Tsui et al., 1997) has advanced the literature by identifying distinct parts of the HR system that may differentially affect employee performance. Performance-enhancing practices are short-term incentives designed to respond to immediate competitive pressures to improve performance. They may include behavior-oriented measures (electronic monitoring, performance appraisals) and outcome-oriented measures, such as pay linked to employee performance. While theory suggests that they are often substitutes (outcome measures used for hard-to-monitor jobs), in fact, employers often view them as complementary. Where good service is viewed as an antecedent to sales (Schlesinger \& Heskitt, 1991), as in service and sales settings, electronic systems monitor the quality of service interactions while commission pay provides incentives for sales.

In theory, more extensive use of performance monitoring creates higher expectations and more onerous working conditions, leading to higher quit rates. Employees typically view ongoing electronic monitoring as an invasion of privacy and an indication of lack of trust, leading even 'good performers' to be dissatisfied and quit. Empirical studies show that electronic monitoring is significantly linked to higher job-related stress (Carayon, 1993; Deery et al., 2002; Holman, Chissick, \& Totterdell, 2002), an antecedent to voluntary turnover (de Croon, Sluiter, 
Blonk, Broersen \& Frings-Dresen 2004), and higher quit rates (Batt et al., 2002; Shaw et al 1998; Wilson \& Peel, 1991). It also should lead to higher dismissals because it provides accurate information about performance, assuaging employer uncertainty about whether claims of poor performance are accurate (Klaas, Brown \& Henemann, 1998). However, the only study of these relationships found a positive relationship between performance appraisals and dismissals, but none between monitoring and dismissals (Shaw et al., 1998).

Performance-based pay, by contrast, provides an outcome measure that sorts employees according to their ability to meet objective standards (Gerhart $\&$ Rynes 2003). The predictions for the relationship between performance-based pay and dismissals are consistent with our arguments regarding electronic monitoring. Pay-for-performance (in this case, commissionbased pay) provides clear, objective measures that allow employers to more accurately identify poor performers and dismiss them.

The predictions for overall quit rates are less straightforward. They depend on the net effect of four factors. First, employees who perform poorly under these pay plans are likely to quit more, either because they find them onerous or because they anticipate being fired. Second, employees who perform well under these plans are likely to quit less than they otherwise would because they earn more (Harrison, Virick, \& William, 1996; Lazear, 1999). One department store study found higher earnings for workers who received a base salary plus commission, rather than either a base salary alone or a commission alone (Patterson, 1992). Third, employees who perform well under these plans may nonetheless quit because they experience greater jobrelated stress - pressure to sell and to be 'on' all day in order to make their commissions.

A fourth factor that affects quit rates is the level of pay that is at risk and the level of risk aversion of the workforce. Most research on pay-for-performance has focused on pay that is not 
at-risk (individual bonuses, merit pay, gain-sharing, profit-sharing over and above an employees' normal pay) (Gerhart \& Rynes, 2003). Commission pay is pay-at-risk, making weekly wages variable and uncertain. In addition, factors beyond workers' control affect their commission levels: changing economic conditions, the product's competitiveness, and variation in the customers that employees are assigned to serve. While companies may try to adjust the payout formula to improve the pay-for-performance link, research shows that this is quite difficult to do; and in uncertain market conditions when workers are more likely to be dissatisfied with payouts, employers whose profit margins are uncertain may be reluctant to increase the generosity of commission pay formulas. Thus, the impact of commission pay on quit rates is likely to depend on how risk averse workers are. Risk aversion varies among individual workers, but research has documented two general patterns. First, women have higher risk aversion than men (Byrnes, Miller, \& Schaefer, 1999). Second, workers with lower skill levels and wages have higher risk aversion (Caroli \& García-Peñalosa, 2002). Nadler and Wiswall (2009), for example, found that teacher support for a policy shift from scheduled, fixed-pay increases to merit pay was higher in school districts that offered higher base salaries and had a higher proportion of teachers with masters' degrees (as opposed to bachelors' degrees). Even here, however, the teachers would only support merit pay if their current base salary was guaranteed - that is, no pay-at-risk.

The workforce in the current study is predominantly female (on average 70 percent), does not have a college degree, and receives a relatively low wage - considerably lower than teachers. Assuming that a large proportion of these employees are risk averse, many are likely to prefer the certainty of a stable weekly income over a variable one, even if the variable pay plan offers a somewhat higher annual pay. In this context, therefore, we believe that the net effect of these four factors will yield a positive relationship between the use of commission pay and quit rates. 
Hypothesis 3 : Performance-enhancing practices will be positively related to both quit rates and dismissal rates.

\section{HR Practices, Quits, Dismissals, and Performance}

Theory and evidence on the relationship between HR practices and organizational performance has expanded considerably in the last two decades, although questions remain unanswered. An exhaustive review of empirical studies concluded that, on average, high involvement work systems are associated with significantly higher operational performance (Combs, Liu, Hall, \& Ketchen, 2006); and some recent studies have linked HR practices specifically to better customer satisfaction (Liao \& Chuang, 2004). While studies differ in their approach to measurement, they typically include two dimensions examined here: high involvement work organization and commitment-enhancing investments and inducements. In theory, organizations that make greater use of high involvement work organization should have higher performance because they provide employees with the discretion and opportunity to collaborate to solve problems effectively. Commitment-enhancing incentives motivate employees to use their skills and discretionary effort to advance the interests of the organization.

The concept of performance-enhancing expectations has not been part of the high involvement literature. However, organizations that make more intensive use of these practices should, in theory, experience better performance because these practices are designed to induce employees to meet immediate performance goals.

Hypothesis 4a: High involvement work organization, investment and inducement practices, and performance-enhancing expectations will each individually be associated with higher levels of operational performance. 
Theory also predicts that the synergies from these three types of HR practices should be multiplicative, but some studies have found evidence of interactions (Huselid, 1995; Shaw et al., 2009), while others have not (e.g. Cappelli and Neumark 2004). These mixed findings suggest that it is worthwhile to further explore the synergies of these practices.

Hypothesis $4 \mathrm{~b}$ : The interactions of high involvement work, investment and inducement practices, and performance-enhancing expectations will be associated with higher levels of operational performance than the simple additive effect of these HR practices.

\section{Turnover and Performance}

The theory linking turnover and organizational performance is more equivocal (Bluedorn 1982; Osterman, 1987). The link depends in part on which workers leave, and who they are replaced by. While the literature has assumed that more able employees quit more often, those with valuable firm-specific skills may stay, in part because their skills are less valuable externally. Studies finding that 'better' performers are more likely to quit (Wells \& Muchinsky, 1985; Tang \& Frost, 1999) stack up against those that find the opposite (Martin, Price, \& Mueller, 1981), while McEvoy and Cascio (1987) found a negative relationship between performance and both quits and dismissals, and Trevor and colleagues (1997) showed that high and low performers quit more than do average employees. The phenomenon also may be context specific. For example, Shaw and colleagues (2009) found that quits among good and poor performers in trucking were correlated at .58, but not at all in supermarkets.

Similarly, while theory would argue that dismissing less able employees should improve performance, the only organizational study that differentiates quits and dismissals found the opposite: Higher dismissal rates in bank branches negatively affected customer satisfaction and cost per loan (McElroy, Morrow, \& Rude, 2001) 
Beyond this classic discussion about who quits or is dismissed, another line of argument focuses on the extent to which overall turnover - whatever its source - is dysfunctional because it contributes to higher costs and operational disruption (Hausknecht, Trevor, and Howard, 2009; Watrous, Huffman, \& Pritchard, 2006). Regardless of whether an employee quits or is fired, recruitment and training costs are the same. Short-term productivity may be lower until the new employee becomes fully proficient (Batt, 2002) and longer term performance depends on whether the new recruit is more able than the dismissed employee, which is not certain if the organization's labor pool and selection procedures are unchanged (Hausknecht et al., 2009). High overall turnover may raise transactions costs by: Requiring higher management-to-worker ratios; undermining workplace rules that form the basis of organizational control (Price, 1977); shifting resources and experienced workers away from daily work to train and socialize novices (Staw, 1980); disrupting the social fabric and bonds of trust and social capital that have been shown to positively affect performance (Shaw, Duffy, Johnson, \& Lockhart, 2005); or lowering flexibility for internal redeployment or rotation across different jobs or skill sets.

In sum, the relationship between turnover and performance is likely to be the complex result of multiple contingencies -- depending on the institutional, organizational, and market context of firms and on how performance is measured. Despite theoretical ambiguities, however, the preponderance of evidence is that total turnover and voluntary turnover are both negatively related to operational performance, and specifically to service quality and customer satisfaction (Kacmar, Andrews, Van Rooy, Steilberg, \& Cerrone, 2006; McElroy et al., 2001). These arguments suggest the following hypothesis:

Hypothesis 5a: Quit and dismissal rates will be negatively related to operational performance: 
These theoretical arguments also suggest that whether turnover mediates the relationship between HR practices and performance may depend upon the contingencies discussed above. Studies finding partial mediation for voluntary turnover include those by Huselid (1995), Batt (2002), and Way (2002). However, if indeed quit rates have a negative effect on performance and dismissals have a positive effect, as some have argued (Koys, 2001:111), then the mediating effect may be insignificant. The literature, then, suggests the following hypothesis:

Hypothesis $5 \mathrm{~b}$ : The HR - performance relationship will be mediated by the additive effect of quit rates and dismissal rates.

\section{METHODS}

\section{Sample}

The data for this study come from a 1998 stratified nationally-random survey of call centers in the telecommunications industry, based on the Dun and Bradstreet listing of establishments, and a 2003 nationally-random survey of call centers across all industries. Limiting the sample to organizations providing the same types of services enhances comparability and reduces extraneous sources of variation and measurement error (Becker \& Gerhart, 1996: 792; Osterman, 1994). The longitudinal dataset includes telecommunications industry establishments surveyed in both 1998 and 2003; but due in part to the dot.com bust in the intervening period, only 40 percent of the 1998 sample was able to be identified in 2003 . A response rate of 68 percent for the matched cases yielded a longitudinal sample of 97 centers.

Identifying the 2003 population of call centers across industries was difficult because there is no official data on call centers, and many are located within larger organizations. By contrast, as a large proportion of establishments in telecommunications are call centers, they could be easily identified via initial screening. As a result, for 2003, we used the Call Center Magazine 
subscription list, with over 60,000 subscribers. We pulled a random sample of subscribers who were listed as the general directors or managers of their centers, stratified by the industry they served. After exclusions for missing data on the variables of interest, the 2003 sample is 339 establishments (including those in the longitudinal sample), while the longitudinal sample is 93.

Both the 1998 and 2003 telephone surveys were administered by a university-based survey research institute to the senior manager at each center. It took 52 minutes on average in 1998 and 45 minutes in 2003. Questions focused on call center agents, defined as the "core" workforce (Osterman, 1994). Given our large, nationally representative sample, it was not feasible to survey multiple respondents at each site. However, Gerhart, Wright, McMahan, and Snell (2000) note that establishment surveys are generally more reliable than corporate-level surveys as the workforce is much smaller, and the managers are generally knowledgeable about the HR practices they are responsible for implementing. The average size of the core workforce was 107 in 1998 and 167 in 2003 ; the median size was 24 in 1998 and 73 in 2003.

The 1998 and 2003 samples differed in minor ways, reflecting the changes in the overall economy as well as differences in the industries covered in the two periods. Mean quit rates were 10.5 percent in the 1998 sample and 14.9 percent in the 2003 sample, while local unemployment rates averaged 4.6 and 5.4 percent respectively. Years of formal education averaged 13.6 years for the typical employee in 1998 and 13.4 years in 2003 . Workforce size increased over time, reflecting the consolidation of operations into larger centers. Workforce size was also smaller in the longitudinal sample. More generally, it is important to recognize that there is an inherent selection bias in the longitudinal data in favor of establishments that continued to operate over this five-year period, likely selecting out poorer performing establishments. 


\section{Measures $^{1}$}

Dependent variables. The four dependent variables provide indicators of quits, dismissals, total turnover, and customer satisfaction. The quit rate is the percentage of workers who quit voluntarily in the past year, while the dismissal rate is the percentage of workers who were dismissed. Total turnover is the percentage of workers who either quit or were dismissed in the past year. These measures exclude promotions, retirements, buy-outs, and lay-offs. Customer satisfaction is constructed from the mean of two standardized items (alpha $=0.59)$ : the average level of customer satisfaction (1-5 scale); and the center's customer satisfaction level compared to other competitors (1-5 scale, with anchors "much lower" and "much higher"). This provides a measure of operational performance, rather than cost-adjusted or financial performance. While this is a subjective measure, it is an important and widely discussed metric in this industry.

Independent variables. We measured high involvement work organization by three variables: The extent of employee discretion; use of problem-solving groups; and use of selfdirected teams (see Batt, 2002). The discretion scale (MacDuffie, 1995; Batt, 2002) is the average of the extent to which employees have discretion (from none (1) to complete (5)) over operational issues, such as: daily tasks or assignments; tools or procedures; the pace or speed of work; setting daily lunch and break schedules; settling customer complaints without a supervisor (alpha $=.77)$. Problem-solving groups is the percentage of workers involved in off-line groups with supervisors to discuss work-related issues. Self-directed teams is the percentage of workers organized into on-line semi-autonomous teams. The high imvolvement work index is the mean of the standardized values of discretion, problem-solving groups, and self-directed teams.

\footnotetext{
1 Detailed definitions of all variables are found in Appendix 1.
} 
All three of our HR indexes (high involvement work organization, investment and inducement practices, and performance enhancing practices) are additive -- conceptualized as composed of substitutable elements, which provide alternative means of achieving the same objective. We treat them as additive indices rather than as items in a scale representing an underlying latent variable - an approach well-established in the HR-Performance literature (Appelbaum et al. 2000; Batt 2002; Shaw et al. 2009).

Investment and inducement practices are a slightly modified version of Shaw et al.'s measure $(1998 ; 2009)$, which captures the use of internal labor market practices (internal mobility opportunities, relative pay, pensions, and employment security). Internal mobility opportunities are measured by the percentage of the core workforce promoted to higher positions or transferred within the larger organization. Transfers allow employees to move to jobs that provide experience for subsequent promotions or offer preferable working conditions or locations. Relative pay is the average annual pay (in dollars) of the typical (median) core worker, relative to the median wage of customer service employees in the metropolitan area or county in which the establishment is located (Bureau of Labor Statistics, 2001). This definition of pay measures the relative attractiveness of the current job compared to local alternatives, which is likely to influence turnover decisions. The pension variable is a dichotomous variable, which equals 1 if employees are covered by a defined benefit pension plan, a type of long-term deferred compensation benefit used to tie employees to the firm.

Employment security is the proportion of the workforce that is full-time and permanent, as opposed to contingent (part-time or temporary). While some argue that contingent workers may serve as a buffer to protect full time workers, research shows that they are often used for costcutting (Houseman, 2001); and quit rates among core workers are higher in establishments 
making greater use of contingent workers (Batt et al, 2002). In these cases, firms send a signal to core employees that their jobs are insecure because future cost-cutting may lead to converting more core jobs to contingent positions. In addition, the availability of contingent workers as substitutes for core employees puts downward pressure on the wages of incumbent employees (Katz and Krueger, 1999; Houseman, 2001), thereby unintentionally inducing higher quit rates among these employees. Combining these four measures, we constructed a standardized additive index of investments and inducements. The first three measures are also used in the Shaw et al. (2009) investments and inducements index. We add the fourth measure, internal mobility opportunities to capture the internal labor market theory based arguments that this is a key practice indicating long-term investments in and inducements for the workforce.

Performance enhancing practices are measured by two commonly used practices in call centers: Monitoring intensity and individual commission pay. Monitoring intensity is the average of three questions: How often core employees receive statistics on performance; how often their calls are listened to by supervisors; and how often they get feedback on phone technique (frequency scale of $1-8$, where $1=$ never and $8=$ daily) (Alpha $=.66)$. Commission pay is the percentage of annual earnings of the typical core worker that comes from individual commissions (at risk pay). In this sample, 57.8 percent of establishments made no use of commission pay. Of the remaining 42.2 percent of establishments that made some use of it, the mean percentage of total pay that was commission pay was $27.1 \%$. Overall, 11.2 percent of establishments had 1-9 percent of pay at risk; 15.6 percent had 10-25 percent at risk; 5.6 percent had 26-50 percent at risk; and 5.9 percent had $>50-100 \%$ at risk.

We standardized the monitoring and commission pay variables and constructed a standardized additive performance-enhancing practices index. Our approach is similar to that of 
Shaw et al. (2009), who also used monitoring and performance-based pay in their expectationsenhancing practices index.

Control variables. We included several variables to control for market, organizational, and workforce characteristics. The local umemployment rate controls for variation in labor market conditions: Higher unemployment rates or alternative job opportunities are negatively correlated with turnover (e.g., Carsten \& Spector 1987; Gerhart 1990). We control for industry (telecommunications versus others) as telecommunications is over-represented in the sample Union coverage is a dichotomous variable $(1=$ yes, $0=$ no $)$, as a core workforce is legally defined as one bargaining unit, with complete union coverage or none at all. Controls for ownership include whether the center is in-house (owned by a primary firm, $1=$ yes) or outsourced (owned by a subcontractor). A series of dummy variables captures the primary segment served by the center: large business, small business, residential clients, or all segments (the omitted category). We control for workforce size, (of the core workforce), as larger establishments may have more turnover due to a more standardized work environment. We also control for the age of the establishment, as older establishments may have more stable employment systems; and whether it had recent layoffs (in the last year), as research has shown that downsizing may undermine employee commitment, leading to higher quit rates (Trevor \& Nyberg, 2008).

To control for the human capital and demographic characteristics that may influence employees' relative ease of movement, we include: The percentage of the workforce that is female (percent female); the average number of years of education of the typical worker at the site (average education) (Bretz, Boudreau, \& Judge, 1994; Trevor 2001); and the number of weeks of initial training and on-the-job experience for workers to become fully qualified (initial training). These human capital controls are important to our argument because they help us to 
identify the degree to which employment systems, rather just a higher quality workforce, affect quits, dismissals, and performance. Two particularly important control variables capture selection practices, as selectivity is a major competing explanation for variation in quits and dismissals. We measure the selection ratio as the percentage of applicants hired by the establishment and systematic selection procedures as the proportion of the core workforce that has been selected using systematic selection tests (psychometric tests or aptitude tests).

\section{RESULTS}

Table 1 presents the means, standard deviations, and bi-variate correlations for the variables. The average annual quit rate in this sample is 14.9 percent, the dismissal rate is 9.8 percent, and average total turnover is 24.7 percent (with a range of close to zero to over 100 percent). Note that the dismissal rate is much higher than prior studies of banking $(5 \%$, McEloy et al. 2001) or truckers (5.9\%, Shaw et al. 1998), which may be partly due to the effectiveness of electronic monitoring in calling centers for identifying poor performers. Table 2 presents the estimation equations for the first three dependent variables (quits, dismissals, and total turnover), using the cross-sectional sample. Table 3 replicates these equations, using the longitudinal sample, with lagged HR index variables from 1998 to estimate turnover outcomes in 2003 . Table 4 presents the equations for customer satisfaction, using the cross sectional sample.

\section{- Table 1 about here -}

Beginning with the simple bi-variate correlations, we find a striking degree of similarity in the predicted HR factors for both quits and dismissals. The high involvement work index is associated with lower quits $\left(\mathrm{r}=-0.28^{*}\right)^{2}$ and lower dismissals $\left(\mathrm{r}=-0.18^{*}\right)$. The results are similar for the individual practices in this index, including worker discretion $\left(r=-0.25^{*}\right.$ for quits and $r=$ $0.20 *$ for dismissals), problem-solving groups $(\mathrm{r}=-0.23 *$ for quits and $\mathrm{r}=-0.14 *$ for dismissals $)$ 
and self-directed teams ( $\mathrm{r}=-0.12 *$ for quits and $\mathrm{r}=-0.04$ for dismissals). Similarly, the investments and inducements index is significantly associated with both lower quits $\left(\mathrm{r}=-0.33^{*}\right)$ and lower dismissals $\left(\mathrm{r}=-0.25^{*}\right)$. Individual practices comprising this index also have parallel results, as seen for internal promotion ( $\mathrm{r}=-0.20^{*}$ for quits and $\mathrm{r}=-0.22 *$ for dismissals), relative pay ( $\mathrm{r}=$ $0.22 *$ for quits and $r=-0.09$ for dismissals), pensions $\left(r=-0.10\right.$ for quits and $r=-0.20^{*}$ for dismissals), and full-time and permanent workforce $(r=-0.27 *$ for quits and $r=-0.11 *$ for dismissals). The performance-enhancing practices index is positively correlated with both quits $\left(\mathrm{r}=0.24^{*}\right)$ and dismissals $\left(\mathrm{r}=0.22^{*}\right)$, with parallel associations for the components of this index -monitoring intensity $\left(\mathrm{r}=0.27 *\right.$ for quits and $\mathrm{r}=0.20^{*}$ for dismissals) and commission pay ( $\mathrm{r}=0.08$ for quits and $\mathrm{r}=0.11^{*}$ for dismissals). Thus, for all of the HR indexes and individual practices, we find initial support for the hypotheses 1,2 , and 3, suggesting similar antecedents for quits and dismissals. To further investigate these relationships, we now turn to our multivariate models.

- Table 2 about here -

\section{Multivariate Analyses}

Estimation of multivariate models for our dependent variables requires accounting for the functional form of these variables, which are measured as rates, and therefore have a lower bound of zero (negative values are impossible). This produces a censored distribution, where only part of the normal distribution is observed. Ordinary least squares (OLS) estimates for censored distributions produce biased estimates. To produce consistent estimates of the parameters, it is necessary to use a Tobit model for the estimation (Long 1997: 187-9).

We begin by estimating base models consisting of market, organizational, and workforce controls as predictors of quits, dismissals, and total turnover (models 1a, 1b, and 1c in table 2).

\footnotetext{
$2 *$ Indicates significance at the $\mathrm{p}<05$ level.
} 
Next we add the set of three HR indexes (models $2 a, 2 b$, and $2 c$ in table 2). Finally, we examine the interaction terms for the three HR indexes (model $3 a, 3 b$, and $3 c$ in table 2).

Use of Tobit models in the estimation complicates the interpretation of effect sizes: The Tobit coefficients represent changes in the latent variable $y^{*}$, rather than the censored variable $y$. For interpretation of effect sizes, the Tobit coefficients need to be multiplied by the appropriate conversion factors to produce the change in the observed censored variable y (Long 1997) ${ }^{3}$ For ease of interpretation, all effect sizes for variables in our Tobit models are reported in the text and tables as marginal effects in terms of percentage point changes in the observed dismissal, quit, and total turnover rates, calculated at the means of the variables.

In the analyses, we found strong support for hypothesis 1: Organizations that make greater use of high-involvement work practices have significantly lower quit rates $(p<.001$, model $2 a$, table 2), lower dismissal rates ( $p<.05$, model $2 b$, table 2$)$, and lower total turnover $(p<.001$, model 2c, table 2). A one standard deviation increase (0.67) in the high-involvement index is associated with a 3.4 percentage point lower quit rate $\left(0.67^{*}-5.04\right)$, a 1.4 percentage point lower dismissal rate, and a 4.5 percentage point decrease in total turnover.

We also found strong support for hypothesis 2 : The investments and inducements index is significantly associated with lower quits ( $<<.05$, model $2 a$, table 2 ), dismissals ( $p<.05$, model $2 b$, table 2), and total turnover ( $\mathrm{p}<.01$, model $2 \mathrm{c}$, table 2$)$. A one standard deviation increase $(0.63)$ in the investments and inducements index yields a 1.9 percentage point lower quit rate, a 1.5 percentage point lower dismissal rate, and a 3.5 percentage point decrease in total turnover.

\footnotetext{
${ }^{3}$ For a tobit model with a lower limit, the formula for the total change in the observed variable $y$ is $F(z) B$, where $B$ is the unadjusted tobit coefficient and $F(z)$ is the cumulative density function for the probability of the observation being uncensored (Long 1997: 209).
} 
Similarly, the performance-enhancing incentives index has the same (positive) relationship with quits and dismissals (Table 2). Organizations that make greater use of performance incentives have significantly higher quit rates ( $p<.001$, model $2 a)$, higher dismissal rates $(p<.001$, model $2 \mathrm{~b}$ ), and higher total turnover ( $\mathrm{p}<.001$, model $2 \mathrm{c}$ ). A one standard deviation $(0.65)$ increase in the performance-enhancing index is associated with a 3.3 percentage point higher quit rate, a 2.0 percentage point higher dismissal rate, and a 5.2 percentage point increase in total turnover. In sum, for all three HR indexes, the relationships between the index and both quits and dismissals are highly significantly and in the same direction.

We investigated the possibility of interactions between the different HR indexes, which might indicate either complementarities or incompatibilities between these different approaches to HR management. Among the two-way interactions, the only significant result was for the interaction between the high involvement index and the performance-enhancing index and quits ( $\mathrm{p}<.05$, model 2a, table 2 ). The same interaction term for total turnover was marginally significant ( $\mathrm{p}<.10$, model $2 \mathrm{c}$, table 2 ). These results indicate that the combination of higher scores on both of these indexes were associated with higher quits and higher total turnover. A three-way interaction term was tested as well (in analysis not shown), but was not significant.

In addition to the findings for the employment systems variables, our results also indicate some interesting relationships between our control variables and both types of turnover. Notably, union representation is associated with significantly lower quit rates ( $<<.001$, models $1 \mathrm{a}$, table 2 ), dismissal rates ( $\mathrm{p}<.05$, model $1 \mathrm{~b}$, table 2$)$, and total turnover $(\mathrm{p}<.001$, model $1 \mathrm{c}$, table 2$)$. Compared to nonunion workplaces, the average union workplace has a 9 percentage point lower quit rate, a 4 percentage point lower dismissal rate, and a 13 percentage point lower total turnover rate. The association between union representation and lower quit rates supports 
predictions from exit-voice theory that the union collective voice mechanism will reduce the use of the exit option of quitting in response to dissatisfaction (Freeman, 1980). This theory may also explain the negative association between union representation and dismissals as the voice mechanism may allow employees to correct poor performance before it leads to dismissal. Alternatively, it can be explained by just cause protections and effective union grievance procedures, which reduce the ability of management to dismiss employees (Colvin 2003).

Also of interest is that establishments in labor markets with higher unemployment have significantly higher dismissal rates ( $p<.001$, model $1 \mathrm{~b}$, table 2 ). Managers in these contexts may feel more latitude to dismiss under-performing or marginal employees as the local labor market provides a ready supply of potential replacements. Among other controls, establishments that employ a higher educated workforce have significantly lower dismissal rates ( $\mathrm{p}<.001$, model $1 \mathrm{a}$, table 2), perhaps reflecting better job performance by employees with higher education or managerial assumptions that more educated workers are more trainable. Also, as anticipated, selection practices are significant: Organizations with higher selection ratios (lower selectivity in hiring) have significantly higher quits ( $<<.05$, model la, table 2 ), higher dismissals ( $<<.01$, model $1 \mathrm{~b}$, table 2 ), and higher total turnover ( $\mathrm{p}<.01$, model $1 \mathrm{c}$, table 2 ).

In a series of additional analyses (not shown) we explored the effects of other control variables. These included measures of differences in the types of services and sales that a center offers, as well as the level of competitiveness of the product market, which Bloom and Van Reenan (2006) show to be a powerful predictor of the adoption of good management practices. (Our competitiveness measure was whether the market was local/regional, national, or international in scope). These controls were not significant and did not change our findings. We also included a dummy variable in the longitudinal analyses for those establishments that had 
switched to commission pay between the two time periods ( 11 percent of the sample). We found no significant effect and the findings did not change, suggesting that quits are not entirely driven by lower performing employees who quit because of the introduction of a new system.

\section{- Table 3 about here -}

We now turn to the analysis of our longitudinal data, which enables us to examine whether the use of HR practices in one time period has an effect on subsequent turnover. Turnover rates from our 2003 sample are regressed on lagged HR practice indexes from our 1998 sample. The five year lag period between the surveys in our study is longer than some other longitudinal studies. This has the disadvantage that if effects attenuate over time, it will be less likely that we will find significant effects of our 1998 predictors on our 2003 outcomes. At the same time, the relatively longer lag period makes for a more conservative test of our hypotheses, increasing our confidence that any significant effects we find are causal in nature.

The results of the longitudinal analysis mirror those found in Table 2, but as expected, the significance levels are lower given the much smaller sample size of 93 establishments. The lagged high involvement work index is associated with significantly lower quits ( $<<.05$, table 3 ), lower dismissals (though not significantly), and significantly lower total turnover $(\mathrm{p}<.10$, table 3). The lagged performance-enhancing index is associated with significantly higher quits $(\mathrm{p}<.001$, table 3$)$, higher dismissals $(\mathrm{p}<.05$, table 3$)$, and higher total turnover $(\mathrm{p}<.001$, table 3$)$. The associations for the lagged investments and inducements index are negative, but not significant. Thus, the longitudinal analysis supports the results of the cross-sectional analysis for the effect of performance-enhancing practices, and partially supports the effect of high involvement work practices. It is noteworthy that the longitudinal results provide some 
consistent findings, given that we used a relatively conservative test involving a relatively long (five year) lag period and a considerably smaller sample size.

- Table 4 about here -

In Table 4, we present the results of our analysis of HR practices, turnover, and customer satisfaction. As in the analyses for turnover, we begin with a base model that includes only the control variables (model 1), then add the three HR indexes (model 2), and finally the interactions among the HR indexes (model 3). Our results show only partial support for hypothesis 4a: The high involvement index has a significant positive association with customer satisfaction $(\mathrm{p}<.01$, model 2, table 4), but the other two indexes are not significant. A one standard deviation increase in the high-involvement index is associated with a 0.20 standard deviation increase in customer satisfaction (model 2, table 4). Also, there are no significant effects on customer satisfaction for two-way interactions between the HR indexes (model 3, table 4) or for a three-way interaction (analysis not shown), so hypothesis $4 \mathrm{~b}$ was not supported.

In the next three sets of models in Table 4, we examine the relationship between customer satisfaction and quit rates (model 4), dismissal rates (model 5), and total turnover (model 6). We find that organizations with higher quit rates have significantly lower customer satisfaction rates $(\mathrm{p}<05$ ); those with higher total turnover (quits and dismissals combined) have significantly lower customer satisfaction ( $\mathrm{p}<.05$ ). The relationship between dismissals alone and customer satisfaction is negative, but not significant. In terms of effect sizes, a one standard deviation increase in total turnover (i.e. an increase of 24.2 percentage points in the rate of quits plus dismissals) is associated with a 0.12 standard deviation decrease in customer satisfaction. These findings are consistent with hypothesis $5 \mathrm{a}$, (which predicted that organizations with higher dismissals would have lower customer satisfaction). Model 6 also examines whether total 
turnover mediates the relationship between the HR practices and customer satisfaction. Recall that all three HR indices are significantly related to total turnover (Table 2), and only the high involvement work index is significantly related to customer satisfaction (Table 4, model 2).

We find that total turnover partially mediates the relationship between high involvement work organization and customer satisfaction. Following the standard mediation test procedures (Baron \& Kenny, 1986; Muller, Judd \& Yzerbyt, 2005), the high involvement index was a significant predictor of customer satisfaction (step 1 of the mediation test, model 2, table 4) and a significant predictor of total turnover (step 2, model 2c, table 2). When both the high involvement index and total turnover are included in the model, total turnover is a significant predictor of customer satisfaction (step3, model 6, table 4). When total turnover is included as a control (step 4), the coefficient of the high involvement index on customer satisfaction is smaller in absolute value $(26.3=>23.8$, models 2 and 6 , table 4$)$. Therefore, hypothesis $5 \mathrm{~b}$ is supported for the high involvement work index, but not for the other HR indexes, which were not significantly related to customer satisfaction.

\section{Additional Analyses}

Although we focus our analysis on our three employment systems indexes, as a check on the robustness of our findings we also estimated models using the individual practices that make up these indexes. These results are shown in Appendix 2 and provide additional confirmation of our general findings. The relationships for almost all of the individual practices are in the same direction as for the indexes (with the exception of relative pay) and a large number of them are significant, albeit given that practices in the same index are capturing similar effects it is unsurprising that there is loss of significance for some variables in the full model. One notable finding is that both electronic monitoring and commission pay have significant positive effects 
on quits, dismissals, and total turnover, which corresponds to our hypotheses and findings for the performance-enhancing practice index. This provides some additional support for our argument that these two practices have similar effects and can be linked together.

In separate analyses (not shown), we further examined our assumption that the commission pay variable has a linear relationship to the outcomes of interest by creating a series of dummies for different levels of pay at risk (none; $1-9 \% ; 10-25 \% ; 26-50 \% ; 51-100 \%$ ). It could be, for example, that people who are less risk averse would self-select into jobs with high levels of commission pay (over $50 \%$ ) and quit less because they are rewarded with higher pay. This was not the case. Relative to no pay at risk (the largest group), each of the 3 groups representing the highest levels of pay at risk $(10-25 \% ; 26-50 \% ; 51-100 \%)$ had significantly higher quits, dismissals, and total turnover and the magnitude of the coefficients for the groups increased as the level of pay at risk increased. Even the first group representing the smallest amount of pay at risk (1-9\%), which was not significant for quits, did have significantly higher dismissals. Thus our results suggest that commission pay does have a linear relationship with quits, dismissals, and total turnover.

We also explored whether the turnover-performance relationship takes on different forms. Some researchers have called for analyses to provide a full empirical record of alternative possibilities, even when the theoretical arguments are ambiguous (Glebbeek and Bax (2004) argued that a curvilinear relationship should always be tested). The research record is mixed on whether the turnover-performance relationship is linear, curvilinear, or contingent on other factors (Alexander et al., 1994; Kacmar et al., 2006; Shaw, Gupta, \& Delery, 2005; Siebert \& Zubanov, 2009). In analyses not shown, we added a squared term for turnover to the turnoverperformance equation and found no evidence of a curvilinear relationship. This is consistent with 
a recent study by Siebert and Zubanov (2009), who found a negative linear relationship between turnover and performance for core workers, but a curvilinear one for part-time workers who were a secondary workforce. As our study is of 'core workers', our findings of a negative linear relationship are consistent with this recent study.

Some also have argued that turnover should moderate the HR-performance relationship because turnover should be more costly for organizations that have invested more in the workforce. Again, the research record is mixed on this point (Arthur, 1994; Shaw et al., 2005b; Ton \& Huckman, 2008). In analyses not shown, we included interaction terms between total turnover and each of the three HR indices. Among the three interaction terms, one reached a modest level of significance $(p<.10)$ : the interaction of turnover and the high involvement index was negatively related to customer satisfaction. This would suggest that the lower the total turnover rate, the stronger the effect of the high-involvement work index on customer satisfaction. Put differently, high turnover would appear to weaken the performance enhancing effect of the high-involvement system. At a relatively low total turnover rate of 12.6 percent (a one-half standard deviation lower than the mean), an increase of one standard deviation in the high-involvement index produces a 0.30 standard deviation increase in customer satisfaction. Meanwhile, at a relatively high total turnover rate of 36.8 percent (corresponding to one-half standard deviation greater than the mean rate), the same increase of one standard deviation in the work organization index produces only a 0.13 standard deviation increase in customer satisfaction. Given the modest level of significance for the interaction term, however, these findings should be interpreted with caution.

\section{DISCUSSION}


In this study we took an employment systems approach to understanding how human resource practices affect turnover and performance. We found that quits and dismissals have similar antecedents in HR practices. First, employers that made greater use of high involvement work organization had significantly lower quits, dismissals, and total turnover. Second, those that invested more in the workforce and offered long term incentives (internal promotion opportunities, high relative pay, pensions, and full-time jobs) had significantly lower quits, dismissals, and total turnover. Third, those workplaces featuring higher short-term performance pressures (intensive performance monitoring and commission-based pay) had significantly higher rates of quits, dismissals, and total turnover. Analyses using longitudinal data with lagged HR variables from time 1 predicting quits, dismissals, and total turnover at time 2 provided consistent evidence for these relationships. Since effects tend to attenuate over time, the use of a relatively long five year lag period provided a conservative test of our hypotheses and enhances the likelihood that the relationships we did find are causal in nature. Finally, employers who made greater use of high involvement work organization had significantly higher customer satisfaction rates, while those with higher quits and higher total turnover had significantly lower satisfaction rates.

Whereas past research has generally theorized, and sometimes found, that quits and dismissals have distinct antecedents, we found the opposite to be true. The explanation we proposed is that employers view the level of turnover as a strategic variable that contributes to operational performance and they may achieve different turnover levels via the use of HR practices. We argued that high involvement work organization may, in effect, raise all boats: Employees quit less because their involvement in operational decisions and problem-solving creates more engaging and satisfying jobs; novices and poor performers benefit from the 
structure of learning and motivation created through team-based forms of work. Similarly, drawing on logic of internal labor market theory, as well as efficiency wage theory, we argued that high relative pay and long-term incentives motivate all employees to avoid shirking - the less proficient as well as the more proficient -- because their current job is far more desirable than the external alternatives. Finally, HR practices that enhance performance expectations produce higher quits, as others have argued and found (Shaw et al., 1998), as well as higher dismissals, as the enhanced criteria expose employees who can't keep up.

Notably, our analyses controlled for alternative explanations related to the human capital level of the workforce and the selectivity of hiring practices. In particular, although we found that having a highly educated workforce and hiring a relatively small proportion of applicants are both associated with better performance, high involvement work practices were associated with higher levels of customer satisfaction even when we took into account these human capital related factors.

Similarly, the turnover-performance literature generally has theorized that quits and dismissals should have opposite effects on performance, but the slim empirical evidence that exists does not support this theory. Our study contributes positive evidence that the combined level of quits and dismissals is significantly negatively related to customer satisfaction. This finding is consistent with the argument we made that quits and dismissals both contribute to operational disruption, which incurs the costs of replacing lost employees and undermines stable social relationships that provide the basis for workplace trust and collaboration, or social capital (Leana \& Van Buren III, 1999).

To make sense of our findings, it may also be useful to put them in the context of the call center sector, as we have argued that we believe the dynamics of turnover are highly influenced 
by the context in which organizations operate. While call centers have a widespread reputation of being 'electronic sweatshops', employing low-skilled workers with little attachment to the labor force, in fact we observed a considerable range of variation in business and $\mathrm{HR}$ strategies and turnover in the centers we visited. This variation is evident in the descriptive statistics in this study. The average call center in 2003 offered annual wages of $\$ 33,794$, with a standard deviation of $\$ 17,292$. The telecommunications and banking industries, which are lead users of call centers and represent a large proportion of establishments in this study, have deep legacies of internal labor market practices that have not been entirely eroded. Call centers in the telecommunications sector continue to have high unionization rates ( 33 percent among call center workers), with particularly low quits, dismissals, and overall turnover.

While we cannot empirically link our analysis to the business strategies of companies, our analysis may be picking up differentiation in employment systems and turnover related to differences in the competitive choices that establishments are making. Centers competing on customer loyalty may emphasize low turnover in order to provide high quality, stable, on-going services to customers. They are likely to invest in high involvement work organization and longterm incentives and downplay monitoring and commission pay because the value proposition is based on long-term customer relationships, not on the quick sell. Other call centers compete on high volume, low-cost interactions, leading them to emphasize a Taylorized approach to work design in which the estimated costs of turnover are low because low-skilled labor is viewed as replaceable. In our study, high total turnover was associated with lower customer satisfactionbut this outcome may not be as important to those centers that compete primarily on low costs To the extent that these establishments compete on short-term sales, the intensification of shortterm performance expectations may be particularly beneficial. 
This explanation dovetails with the findings of a recent study of retail, a similar context to call centers, by Sierbert and Zubanov (2009). They differentiated between high commitment and secondary work systems within the same organization and showed that turnover in the secondary system was positive for performance at low levels, but eventually turned negative. Similarly, our findings may be driven by two types of systems operating in different establishments $-\mathbf{a}$ high commitment system with low overall turnover, focused on quality and customer loyalty, and a secondary system with high turnover in centers competing primarily on costs.

There are several limitations to this study. The findings from the call center sector may not generalize to industries with different product and labor market conditions, technologies, skill requirements and work organization. Future research could valuably extend the current analysis to other industries and occupational groups. This study took an organization-level approach, but future research would benefit from multi-level analyses linking the individual and the workplace.

A multi-level approach would also help sort out issues of causality, which we could only address to a limited degree through our lagged model for the longitudinal data. We used a relatively long five-year lag period, which increases the likelihood that effects are not due to simple correlations of variables over short periods of time, but increases the problem that the actual causal effects will become attenuated with time and hence less observable. This raises a larger question, which has not been adequately theorized in the literature, regarding what should be the appropriate time lag for testing a causal model of the relationship between HR practices and outcomes; and of course, this question will also depend on which HR practices and what types of outcomes. For studies of turnover, how long does it take for an employee to become dissatisfied with an employment system and quit? An ideal research design would track individual employees over time and conduct periodic surveys of stayers and leavers, which could 
be aggregated to the organizational level. This approach would also go beyond an analysis of aggregate separation rates to include a more fine-grained study of how quits and dismissals affect the overall capacity of the organization to function and why. Another area for future research is to examine whether there is variation in the types of workers quitting or being dismissed under different types of employment systems. Future research, particularly if it combined organizational and individual level data, could examine the characteristics of the workers involved in turnover and see how this affects organizational outcomes.

Finally, a general limitation of this study is that the data are based on reports from the general manager at each establishment, so we are unable to check for inter-rater reliability. However, the typical establishment in this study was small, and our measures are mostly based on objective information within the ready knowledge of respondents, which was investigated in fieldwork prior to the survey. Also, for this nationally-representative sample of establishments, we could not gather objective performance data, rendering our performance models only suggestive. However, our approach compares favorably to the other studies of voluntary and involuntary turnover that have been published to date - which rely on cross-sectional data and single establishment respondents (Donaghue and Castle, 2006; Shaw et al., 2005b, study 1).

\section{CONCLUSION}

Our study advances the past literature in two main areas. First, contrary to past research in this area, we found strong similarities in the antecedents of both quits and dismissals, suggesting that they are influenced by common processes relating to the type of employment system that exists in each workplace. Second, we found that quits and dismissals combined are significantly negatively related to customer satisfaction. 
We want to emphasize that we are not challenging the notion that the dynamics of quits and dismissals may be different when we examine individual-level behavior or other industry contexts. And clearly, the dismissal of individual employees for poor performance may improve organizational performance if they are replaced by more capable individuals. Rather we are arguing that at the organizational level, the dynamics of quits and dismissals, and their antecedents and consequences, are contingent on many factors. This study presents a plausible theory and suggestive evidence that the relationship between HR practices, quits, and dismissals may function in similar ways in some circumstances. An employment systems lens shifts the unit of analysis to the organization and considers the ways in which employers may view overall turnover as part of the HR system - a set of tools to manage not only performance but headcount levels. The idea that employers search for 'the optimal level of turnover' (Siebert \& Zubanov 2009 ) is an emerging idea, worthy of further investigation. Thus, we believe that the different results that we have found provide the basis for future research that may examine these relationships with more precision and rigor and with other industries, occupations, and organizational contexts. 


\section{REFERENCES}

Abelson, M. \& Baysinger, B. 1984. Optimal and dysfunctional turnover: Toward an organizational level model. Academy of Management Review, 9(2): 331-341.

Alexander, J. A., Bloom, J. R., \& Nuchols, B. A. 1994. Nursing turnover and hospital efficiency: An organization-level analysis. Industrial Relations, 33: 505-520.

Appelbaum, E., Bailey, T., Berg, P., \& Kalleberg, A. 2000. Manufacturing advantage. Ithaca, NY: ILR Press, an imprint of Cornell University Press.

Arthur, J. 1994. Effects of human resource systems on manufacturing performance and turnover. Academy of Management Journal, 37(3): 670-87.

Barker, J. R. 1999. The discipline of teamwork: Participation and concertive control. Thousand Oaks, CA: Sage.

Baron, J. N. \& Burton, M. D. \& Hannan, M. T. 1996. The road taken: The origins and evolution of employment systems in high-tech firms. Industrial and Corporate Change, 5(2): $239-75$.

Baron, R. \& Kenney, D. 1986. The moderator-mediator variable distinction in social psychology research. J. Personality Soc. Psych., 51: 1173-1182.

Batt, R. 1999. Work organization, technology, and performance in customer service and sales. Industrial and Labor Relations Review, 52(4): 539-564.

Batt, R. 2002. Managing customer services: Human resource practices, quit rates, and sales growth, Academy of Management Journal, 45(3): 587-97.

Batt, R., Colvin, A. J. S., \& Keefe, J. 2002. Employee voice, human resource practices, and quit rates: Evidence from the telecommunications industry. Industrial and Labor Relations Review, 55(4): 573-94.

Batt, R., Holman, D., \& Holtgrewe, U. 2009. The globalization of service work: Comparative institutional perspectives on call centers. Introduction to a Special Issue of Industrial and Labor Relations Review 62(4):453-88.

Becker, B., \& Gerhart, B. 1996. Special research forum: Human resource management and organizational performance. Academy of Management Journal, 39(4): 777-985.

Bloom, N., \& Van Reenen, J. 2007. Measuring and explaining management practices across firms and countries Quarterly Journal of Economics, 122(4):1351-1408.

Bluedorn, A. 1982. The theories of turnover: Causes, effects, meanings. In S. Bacharach, (Ed.), Research in the Sociology of Organizations. (pp. 75-128). Greenwich, CT: JAI Press. 
Bretz, R. D., Boudreau, J. W., \& Judge, T. A. 1994. Job search behavior of employed managers Personnel Psychology, 47(2): 275-301.

Bureau of Labor Statistics (BLS). 2001. Occupational Employment Statistics Survey. Washington, D.C.: U.S. Department of Labor. http/stat.bls.gov/oes/home.htm. Accessed on 10/3/2009.

Bureau of Labor Statistics (BLS). 2003. Local Area Unemployment Statistics. Washington, D.C.: U.S. Department of Labor. http.//stats.bls. gov/lau/. Accessed on 10/3/2009.

Byrnes, J. P., Miller, D. C., \& Schaefer, W. D. 1999. Gender differences in risk taking: A metaanalysis. Psychological Bulletin, 125: 367-383.

Cappelli, P., and Chauvin, K. 1991. An interplant test of the efficiency wage hypothesis Quarterly Journal of Economics, 106: 769-94.

Cappelli, P. \& Neumark, D. 2004. External churning and internal flexibility: Evidence on the functional flexibility and core-periphery hypotheses. Industrial Relations, 43(1): 148:82.

Carayon, P. 1993. Effect of electronic performance monitoring on job design and worker stress review of the literature and conceptual-model, Human Factors, 35(3):385-95.

Caroli, E. \& García-Peñalosa, C. 2002. Risk aversion and rising wage inequality. Economics Letters, 77(1): 21-26.

Carsten, J. M., \& Spector, P. E. 1987. Unemployment, job satisfaction and employee turnover: A metanalytic test of the Muchinsky model. Journal of Applied Psychology, 72(3): 75-80

Colvin, A. J. S. 2003. The dual transformation of workplace dispute resolution. Industrial Relations, 42(4): 712-735.

Combs, J., Liu, Y., Hall, A., \& Ketchen, D. 2006. How much do high-performance work practices matter? A meta analysis of their effects on organizational performance. Personnel Psychology, 59(3): 501-28

de Croon, E. M., Sluiter, J. K., Blonk, R. W. B., Broersen, J. P. J. \& Frings-Dresen, M. H. W 2004. Stressful work, psychological job strain, and turnover: A 2-year prospective cohort study of truck drivers. Journal of Applied Psychology 89(3): 442-34.

Dalton, D. R., Krackhardt, D. M., \& Porter, L. W. 1981. Functional turnover: An empirical assessment. Journal of Applied Psychology, 66(6): 716-721.

Dalton, D. R., \& Todor, W. D. 1979. Turnover turned over: An expanded and positive perspective. Academy of Management Review, 4: 225-35. 
Deery, S., Iverson, R. D., \& Walsh, J. 2002. Work relationships in telephone call centers: Understanding emotional exhaustion and employee withdrawal, Journal of Management Studies, 39(4): 471-97.

Deming, W. E. 1982. Out of the crisis. Cambridge, MA: MIT Press.

Donaghue, C., and Castle, N. G. 2006. Voluntary and involuntary nursing home staff turnover Research on Aging, 28:454-72.

Doeringer, P., \& Piore, M. 1971. Internal labor markets and manpower analysis. Lexington, Mass.: Heath and $\mathrm{Co}$

Freeman, R. 1980. The Exit-Voice Tradeoff in the Labor Market: Unionism, Job Tenure, Quits, and Separations. The Quarterly Journal of Economics, 94(3):643- 73.

Fornell, C., Van Amburg, D., Morgeson, F. \& Bryant, B. 2005. The American customer satisfaction index at ten years, ACSI 1994-2004: A summary of findings: implications for the economy, stock returns and management. Ann Arbor, MI: National Quality Research Center, Ross School of Business, U. of Michigan.

Gerhart, B. A. 1990. Voluntary turnover and alternative job opportunities. Journal of Applied Psychology, 75(5): 467-476

Gerhart, B. A., \& Rynes, S. 2003. Compensation: Theory, evidence and strategic implications Thousand Oaks, CA: Sage.

Gerhart, B., Wright, P. M., McMahan, G. C., \& Snell, S. A. 2000. Measurement error in research on the human resources and firm performance relationship: How much error is there and how does it influence effect size estimates? Personnel Psychology, 53(4): 803-34.

Glebbeek, A. C., \& Bax, E. H. 2004 Is high employee turnover really harmful? An empirical test using company records. Academy of Management Journal, 47: 277-286.

Griffeth, R. W., Hom, P. W., \& Gaertner, S. 2000. A meta-analysis of antecedents and consequences of employee turnover: Update, moderator tests, and research implications for the next millennium. Journal of Management, 26: 463-88.

Hackman, J. R. \& Oldham, G. R. 1980. Work Redesign. Reading, MA: Addison-Wesley.

Harrison, D. A., Virick, M., \& William, S. 1996. Working without a net: Time, performance, and turnover under maximally contingent rewards. Journal of Applied Psychology 81(4): 331-45.

Hausknecht, J. P., Trevor, C. O., \& Howard, M. J. 2009. Unit-level voluntary turnover rates and customer service quality: Implications of group cohesiveness, newcomer concentration, and size. Journal of Applied Psychology: 1-8. 
Holman, D., Chissick, C., \& Totterdell, P. 2002. The effects of performance monitoring on emotional labour and well-being in call centres. Motivation and Emotion, 26(1): 57-81.

Hom, P. W., \& Griffeth, R. W. 1995. Employee turnover. Cincinnati: South-Western College Publishing.

Houseman, S. 2001. Why Employers Use Flexible Staffing Arrangements: Evidence from an Establishment Survey. Industrial and Labor Relations Review, 55(1): 149-70.

Huselid, M. A. 1995. The impact of human resource management practices on turnover, productivity, and corporate financial performance. Academy of Management Journal, 38: 63572.

Jacofsky, E. F. 1984. Turnover and job performance: An integrated process model. Academy of Management Review, 9: 74-83.

Kacmar, K. M., Andrews, M. C., Van Rooy, D. L., Steilberg, R. C., \& Cerrone, S. (2006). Sure, everyone can be replaced ... but at what cost? Turnover as a predictor of unit-level performance. Academy of Management Journal, 49: 133-44.

Klaas, B. S., Brown, M., \& Heneman III, H. G. 1998. The determinants of organizations' usage of employee dismissal: Evidence from Australia. Journal of Labor Research 19(1): 149-64.

Knight, K. G., \& Latreille, P. L. 2000. Discipline, dismissals and complaints to employment tribunals. British Journal of Industrial Relations, 38(4): 533-55.

Koys, D. J. 2001. The effects of employee satisfaction, organizational citizenship behavior, and turnover on organizational effectiveness: A unit-level, longitudinal study. Personnel Psychology, $54,101-114$

Lazear, E. P. 1999. Personnel economics: Past lessons and future directions. Journal of Labor Economics, 17: 199-236.

Leana, C. R. \& Van Buren III, H.J. 1999. Organizational social capital and employment practices. Academy of Management Review, 24(3): 538-555.

Lee, T. W. \& Mitchell, T. R. 1994. An alternative approach: The unfolding model of voluntary employee turnover. Academy of Management Review, 19(1):51-89.

Levitt, T. 1972. "Production line approach to services." Harvard Business Review. 50(5):4150 .

Liao, H., \& Chuang, A. 2004. A multilevel investigation of factors influencing employee service performance and customer outcomes. Academy of Management Journal, 47: 41-58. 
Long, J. 1997. Regression models for categorical and limited dependent variables. Thousand Oaks, CA: Sage.

Lovelock, C. \& Wirtz, J. 2005. Services Marketing: People, Technology, and Strategy, $5^{\text {th }}$ edition. Upper Saddle River, NJ. Pearson Prentice Hall.

MacDuffie, J. P. 1995. Human resource bundles and manufacturing performance: Organizational logic and flexible production systems in the world auto industry. Industrial and Labor Relations Review, 48(2): 197-221.

Maertz, C. P., and Campion, M. A. 2004. Profiles in quitting: Integrating process and content turnover theory. Academy of Management Journal, 47: 566-82.

Martin, T. N., Price, J. L., Mueller, C. W. 1981. Job performance and turnover. Journal of Applied Psychology, 66(1): 116-19.

McElroy, J. C., Morrow, P. C., \& Rude, S. N. 2001. Turnover and organizational performance: A comparative analysis of the effect of voluntary, involuntary and reduction-in-force turnover. Journal of Applied Psychology, 86(6): 1294-99.

McEvoy, G. M. \& Cascio, W. F. 1987. Do good or poor performers leave? A meta-analysis of the relationship between performance and turnover. Academy of Management Journal, 30(4): 744-62.

Muller, D., Judd, C. M., \& Yzerbyt, V. Y. 2005. When moderation is mediated and mediation is moderated. Journal of Personality and Social Psychology, 89(6): 852-863.

Nadler, C., \& M. Wiswall. 2009. Risk aversion and Support for merit pay: Theory and evidence from Minnesota's $Q$ Comp Program. NYU Institute for Education and Social Policy, Working Paper \#09-05. http://steinhardt.nyu.edu/iesp/featured/6

Osterman, P. 1987. Turnover, employment security, and the performance of the firm. In M.M. Kleiner et al. (Eds.), Human resources and the performance of the firm. Madison, WI: Industrial Relations Research Association, pp. 275-316.

Osterman P. 1994. How common is workplace transformation and who adopts it? Industrial and Labor Relations Review, 47: 173-88.

Price, J. L. 1977. The study of turnover. Ames: Iowa State University Press.

Schlesinger, L., \& Heskett, J. 1991. Breaking the cycle of failure in services. Sloan Management Review 32(Spring): 17-28

Shaw, J., Delery, J., Jenkins, G. D., Jr., \& Gupta, N. 1998. An organization-level analysis of voluntary and involuntary turnover. Academy of Management Journal, 39(5): 1-15. 
Shaw, J. D., Duffy, M. K., Johnson, J. L., \& Lockhart, D. E. 2005a. Turnover, social capital losses, and performance. Academy of Management Journal, 48: 594-606.

Shaw, J. D., Gupta, N., \& Delery, J. E. 2005b. Alternative conceptualizations of the relationship between voluntary turnover and organizational performance. Academy of Management Journal, 48: $50-68$

Shaw, J. D., Dineen, B. R, Fang, R., \& Vellella, R. 2009. Employee-organization exchange relationships, HRM practices, and quit rates of good and poor performers. Academy of Management Journal. Forthcoming.

Siebert, W. S., \& Zubanov, N. 2009. Searching for the optimal level of employee turnover: A study of a large U.K. retail organization. Academy of Management Journal, 52(2): 294-313.

Staw, B. M. 1980. The consequences of turnover. Journal of Occupational Behavior, 1: 253273.

Sturman, M. C., Trevor, C. O., Boudreau, J., \& Gerhart, B. 2003. Is it worth it to win the talent war? Using turnover research to evaluate the utility of performance-based pay. Personnel Psychology, 56: 997-1035.

Tang, T. L. \& Frost, A. G. 1999. Employee turnover revisited: Differences among involuntary turnover, voluntary turnover, and current employees. Journal of Compensation and Benefits, 1 : 41-46.

Ton, Z. \& Huckman, R. S. 2008. Managing the impact of employee turnover on performance: The role of process conformance. Organization Science, 19(1): 56-68

Trevor, C. O. 2001. Interactions among actual ease-of-movement determinants and job satisfaction in the prediction of voluntary turnover. Academy of Management Journal,44(4) $621-638$

Trevor, C. O., Gerhart, B., \& Boudreau, J. 1997. Voluntary turnover and job performance: Curvilinearity and the moderating influences of salary growth and promotions. Journal of Applied Psychology, 82: 44-61.

Trevor, C. O., \& Nyberg, A. J. 2008. "Keeping your headcount when all about you are losing theirs: Downsizing, voluntary turnover rates, and the moderating role of HR practices. Academy of Management Journal, 51(2):259-276.

Trist, E. 1981. The sociotechnical perspective: The evolution of sociotechnical systems as a conceptual framework and as an action research program. In Perspectives on Organization Design and Behavior, Van de Ven, A. \& Joyce, W., eds., 19-75. New York: Wiley. 
Tsui, A. S., Pearce, J. L., Porter, L.W., \& Tripoli, A. M. 1997. Alternative approaches to the employee-organization relationship: Does investment in employees pay off? Academy of Management Journal, 40: 1089-121.

Wanous, J. P., Stumpf, S. A., \& Bedrosian, H. 1979. Job survival of new employees. Personnel Psychology, 32(4): 651-662.

Watrous, K. M., Huffman, A. H., \& Pritchard, R. D. 2006. When coworkers and managers quit: The effects of turnover and shared values on performance. Journal of Business and Psychology, 21(1): 103-126.

Way, S. 2002. High performance work systems and intermediate indicators of firm performance within the U.S. small business sector. Journal of Management, 28:765-85

Welch, J., with Welch, S. 2005. Winning: The ultimate business how to book. N.Y., N.Y: HarperCollins Publishers

Wells, D. L., \& Muchnisky, P. M. 1985. Performance antecedents of voluntary and involuntary managerial turnover. Journal of Applied Psychology, 70(2): 329-336.

Wilson, N., \& Peel, M. J. 1991. The impact on absenteeism and quits of profit-sharing and other forms of employee participation. Industrial and Labor Relations Review, 44(3): 454-68.

Wood, S., Holman, D., \& Stride, C. 2006. Human resource management and performance in UK call centres. British Journal of Industrial Relations, 44: 99-124. 
Table 1: Means, Standard Deviations and Bivariate Correlations for Variables

\begin{tabular}{|c|c|c|c|c|c|c|c|c|c|c|c|c|c|c|c|c|c|c|c|c|}
\hline & Variable & Mean & S.D. & 1 & 2 & 3 & 4 & 5 & 6 & 7 & 8 & 9 & 10 & 11 & 12 & 13 & 14 & 15 & 16 & 17 \\
\hline $\bar{I}$ & Quit rate & 14.88 & 16.88 & 1 & & & & & & & & & & & & & & & & \\
\hline 2 & Dismissal rate & 9.81 & 12.04 & 0.38 & 1 & & & & & & & & & & & & & & & \\
\hline 3 & Total turnover & 24.69 & 24.18 & 0.89 & 0.76 & 1 & & & & & & & & & & & & & & \\
\hline 4 & Customer satisfaction & -0.02 & 0.89 & -0.14 & -0.12 & -0.16 & 1 & & & & & & & & & & & & & \\
\hline 5 & High involvement work index & -0.11 & 0.67 & -0.28 & -0.18 & -0.29 & 0.16 & 1 & & & & & & & & & & & & \\
\hline 6 & Worker discretion & 2.87 & 0.74 & -0.25 & -0.20 & -0.28 & 0.13 & 0.71 & 1 & & & & & & & & & & & \\
\hline 7 & Problem-solving groups & 33.80 & 37.07 & -0.23 & -0.14 & -0.23 & 0.11 & 0.70 & 0.22 & 1 & & & & & & & & & & \\
\hline 8 & Self-directed teams & 16.02 & 33.12 & -0.12 & -0.04 & -0.10 & 0.10 & 0.72 & 0.29 & 0.26 & 1 & & & & & & & & & \\
\hline 9 & Investments and inducements index & -0.21 & 0.63 & -0.33 & -0.25 & -0.35 & 005 & 0.38 & 0.36 & 0.29 & 0.16 & 1 & & & & & & & & \\
\hline 10 & Internal mobility opportunities & 0.21 & 0.29 & -0.20 & -0.22 & -0.25 & 0.04 & 0.19 & 0.12 & 0.22 & 0.08 & 0.57 & 1 & & & & & & & \\
\hline 11 & Relative pay & 0.33 & 0.16 & -0.22 & -0.09 & -0.20 & 006 & 0.38 & 0.43 & 0.21 & 0.18 & 0.64 & 0.14 & 1 & & & & & & \\
\hline 12 & Pensions & 0.48 & 0.50 & -0.10 & -0.20 & -0.17 & 0.03 & 0.02 & 0.05 & 0.06 & -0.07 & 0.52 & 0.11 & 0.14 & 1 & & & & & \\
\hline 13 & Full-time and permanent & 0.75 & 0.35 & -0.27 & -0.11 & -0.25 & -0.03 & 0.33 & 0.29 & 0.21 & 0.19 & 0.68 & 0.19 & 0.29 & 0.03 & 1 & & & & \\
\hline 14 & Performance-enlhancing practices index & 0.15 & 0.65 & 0.24 & 0.22 & 0.28 & 0.01 & -0.16 & -0.07 & -0.19 & -0.07 & -0.16 & -0.15 & 0.01 & -0.10 & -0.13 & 1 & & & \\
\hline 15 & Monitoring intensity & 0.04 & 0.66 & 0.27 & 0.20 & 0.29 & 0.00 & -0.41 & -0.38 & -0.27 & -0.22 & -0.36 & -0.16 & -0.45 & -0.04 & -0.25 & 0.54 & 1 & & \\
\hline 16 & Commission pay & 0.11 & 0.22 & 0.08 & 0.11 & 0.11 & 0.00 & 0.12 & 0.20 & -0.04 & 0.09 & 0.09 & -0.06 & 0.34 & -0.10 & 0.04 & 0.78 & -0.12 & 1 & \\
\hline 17 & Unemployment rate & 5.36 & 1.35 & -0.07 & 0.19 & 0.04 & -0.07 & -0.02 & -0.06 & -0.04 & 0.06 & -0.01 & -0.02 & 0.05 & -0.09 & 0.03 & 0.02 & 0.06 & -0.01 & 1 \\
\hline 18 & Telecommunications industry & 0.42 & 0.49 & -0.15 & 0.00 & -0.11 & 000 & 0.21 & 0.25 & 0.12 & 0.08 & 0.23 & 0.04 & 0.16 & -0.03 & 0.36 & 0,02 & -0.20 & 0.18 & $-0,08$ \\
\hline 19 & Union represented & 0.08 & 0.28 & -0.16 & -0.13 & -0.18 & 0.01 & -0.12 & -0.05 & -0.09 & -0.11 & 0.17 & 0.12 & 0.07 & 0.24 & 0.02 & -0.08 & -0.04 & -0.06 & 0.00 \\
\hline 20 & In-house center & 0.86 & 0.35 & -0.12 & -0.13 & -0.15 & -0.01 & 0.18 & 0.18 & 0.15 & 0.05 & 0.31 & 0.15 & 0.17 & 0.11 & 0.28 & -0.13 & -0.24 & 0.02 & -0.07 \\
\hline 21 & Large business clients & 0.24 & 0.43 & -0.10 & 0.02 & -0.06 & -0.02 & 0.20 & 0.17 & 0.18 & 0.09 & 0.22 & 0.01 & 0.43 & 0.06 & 0.06 & -0.04 & -0.18 & 0.10 & 0.07 \\
\hline 22 & Small business clients & 0.10 & 0.30 & -0.12 & -0.13 & -0.15 & 0.02 & 0.02 & 0.06 & -0.06 & 0.03 & 0.06 & 0.04 & 0.07 & -0.10 & 0.13 & 0.07 & -0.07 & 0.13 & 0.08 \\
\hline 23 & Residential clients & 0.35 & 0.48 & 0.10 & 0.05 & 0.09 & -0.05 & -0.17 & -0.18 & -0.12 & -0.06 & -0.19 & -0.09 & -0.24 & 0.02 & -0.16 & 0.06 & 0.19 & -0.06 & -0.04 \\
\hline 24 & Non-segmented clients & 0.32 & 0.47 & 0.07 & 0.02 & 0.06 & 006 & -0.02 & -0.01 & 0.00 & -0.04 & -0.05 & 0.06 & -0.19 & -0.01 & 0.02 & -0.08 & 0.02 & -0.11 & -0.08 \\
\hline 25 & Workforce size & 1.67 & 3.77 & 0.12 & 0.06 & 0.11 & 0.03 & -0.18 & -0.09 & -0.19 & -0.12 & -0.08 & 0.02 & -0.13 & -0.02 & -0.06 & 0.10 & 0.20 & -0.03 & 0.15 \\
\hline 26 & Female workforce & 0.66 & 0.24 & 0.12 & -0.04 & 0.06 & 0.03 & -0.27 & -0.30 & -0.13 & -0.14 & -0.27 & -0.12 & -0.45 & 0.02 & -0.12 & -0.11 & 0.22 & -0.30 & -0.08 \\
\hline 27 & Average education & 13.37 & 1.56 & -0.20 & -0.16 & -0.22 & 0.10 & 0.35 & 0.39 & 0.21 & 0.15 & 0.38 & 0.12 & 0.52 & 0.08 & 0.21 & -0.06 & -0.33 & 0.18 & 0.06 \\
\hline 28 & Initial training & 0.35 & 0.40 & -0.16 & -0.15 & -0.19 & 0.07 & 0.07 & 0.13 & 0,03 & -0.01 & 0.18 & 0.10 & 0.15 & 0.06 & 0.11 & 0,01 & -0.20 & 0.15 & 0.00 \\
\hline 29 & Selection ratio & 0.27 & 0.23 & 0.19 & 0.20 & 0.23 & -0.10 & -0.23 & -0.15 & -0.19 & -0.15 & -0.29 & -0.05 & -0.20 & -0.14 & -0.27 & 0.14 & $0.2 \mathrm{I}$ & 0.00 & 0.01 \\
\hline 30 & Systematic selection procedures & 0.39 & 0.46 & 0.03 & 0.01 & 0.03 & 0.06 & -0.16 & -0.15 & -0.11 & -0.08 & -0.04 & -0.04 & -0.07 & 0.10 & -0.08 & 0.17 & 0.25 & 0.03 & 0.04 \\
\hline 31 & Age of establishment & 14.18 & 13.95 & -0.05 & -0.23 & -0.15 & 0.02 & 0.11 & 0.02 & 0.13 & 0.10 & 0.14 & 0.05 & 0.03 & 0.07 & 0.16 & -0.16 & -0.19 & -0.06 & -0.07 \\
\hline 32 & Recent layoffs & 0.21 & 0.41 & -0.05 & 0.13 & 0.03 & -0.06 & 0.09 & 0.05 & 0.10 & 0.03 & 0.06 & 0.01 & 0.18 & -0.02 & -0.01 & -0.04 & -0.12 & 0.05 & 0.11 \\
\hline
\end{tabular}

Values greater than or equal to 0.11 are significant at $\mathrm{p}<.05$. 


\section{Table 1 (Continued)}

\begin{tabular}{|c|c|c|c|c|c|c|c|c|c|c|c|c|c|c|c|c|}
\hline & Variable & 18 & 19 & 20 & 21 & 22 & 23 & 24 & 25 & 26 & 27 & 28 & 29 & 30 & 31 & 32 \\
\hline$\overline{18}$ & Telecommunications industry & $\vec{l}$ & & & & & & & & & & & & & & \\
\hline 19 & Union represented & 0.09 & 1 & & & & & & & & & & & & & \\
\hline 20 & In-house center & 0.26 & 0.09 & 1 & & & & & & & & & & & & \\
\hline 21 & Large business clients & -0.15 & -0.04 & -0.09 & 1 & & & & & & & & & & & \\
\hline 22 & Small business clients & -0.04 & 0.01 & 0.10 & -0.18 & 1 & & & & & & & & & & \\
\hline 23 & Residential clients & -0.12 & 0.01 & -0.04 & -0.41 & -0.24 & 1 & & & & & & & & & \\
\hline 24 & Non-segmented clients & 0.28 & 0.02 & 0.06 & -0.38 & -0.22 & -0.50 & 1 & & & & & & & & \\
\hline 25 & Workforce size & -0.01 & -0.04 & -0.09 & -0.11 & -0.07 & 0.13 & 0.01 & 1 & & & & & & & \\
\hline 26 & Female workforce & -0.02 & 0.16 & -0.08 & -0.28 & -0.06 & 0.17 & 0.12 & 0.08 & 1 & & & & & & \\
\hline 27 & Average education & -0.01 & -0.08 & 0.13 & 0.28 & 0.09 & -0.13 & -0.18 & -0.11 & -0.45 & 1 & & & & & \\
\hline 28 & Initial training & 0.07 & 0.17 & 0.15 & -0.02 & 0.16 & -0.09 & 0.02 & -0.04 & 0.02 & 0.10 & 1 & & & & \\
\hline 29 & Selection ratio & -0.14 & 0,02 & -0.23 & -0.09 & -0.05 & 0.07 & 0,04 & 0.17 & 0.05 & -0.16 & -0.03 & 1 & & & \\
\hline 30 & Systematic selection procedures & -0.05 & 0.11 & -0.13 & -0.03 & -0.01 & -0.03 & 0.07 & 0.08 & 0.04 & -0.13 & 0.03 & 0.05 & 1 & & \\
\hline 31 & Age of establishment & 0.06 & 0.08 & 0.08 & -0.07 & 0.04 & -0.12 & 0.16 & -0.03 & 0.18 & $-0,08$ & 0.17 & -0.18 & $-0,04$ & & 1 \\
\hline 32 & Recent layotts & -0.02 & -0.05 & -0.13 & 0.16 & -0.04 & -0.08 & -0.04 & -0.03 & -0.16 & 0.12 & -0.02 & -0.03 & -0.02 & -0.10 & \\
\hline
\end{tabular}

Values greater than or equal to 0.11 are significant at $p<.05$. 
TABLE 2

Quits and Dismissals as Functions of High Involvement Work Organization,

Investments and Inducements, and Performance-enhancing Practices (Tobit Models)

\begin{tabular}{|c|c|c|c|c|c|c|c|c|c|c|c|c|c|c|c|c|c|c|}
\hline \multirow{4}{*}{$\begin{array}{l}\text { High involvement work } \\
\text { organization (A) }\end{array}$} & \multicolumn{6}{|c|}{ Quits } & \multicolumn{6}{|c|}{ Dismissals } & \multicolumn{6}{|c|}{ Total Turnover (Quits+Dismissals) } \\
\hline & \multicolumn{2}{|c|}{ Model la } & \multicolumn{2}{|c|}{ Model 2a } & \multicolumn{2}{|c|}{ Model 3a } & \multicolumn{2}{|c|}{ Model lb } & \multicolumn{2}{|c|}{ Model 2b } & \multicolumn{2}{|l|}{ Model 3b } & \multicolumn{2}{|c|}{ Model lc } & \multicolumn{2}{|c|}{ Model 2c } & \multicolumn{2}{|l|}{ Model 3c } \\
\hline & & & $-5,04$ & $* * *$ & -16.16 & $* *$ & & & -2.14 & * & -3.26 & & & & -6.67 & $* * *$ & -20.30 & * \\
\hline & & & $(1.35)$ & & $(5,81)$ & & & & $(0.93)$ & & $(4.04)$ & & & & $(1.90)$ & & $(8.27)$ & \\
\hline \multirow[t]{2}{*}{$\begin{array}{l}\text { Investments and } \\
\text { inducements (B) }\end{array}$} & & & -3.06 & $*$ & -0.88 & & & & -2.32 & * & -5.13 & & & & -5.56 & $* *$ & -7.72 & \\
\hline & & & $(1.47)$ & & $(6.20)$ & & & & $(1.05)$ & & $(4.39)$ & & & & $(2.12)$ & & $(8.91)$ & \\
\hline \multirow[t]{2}{*}{$\begin{array}{l}\text { Performance-enhancing } \\
\text { practices (C) }\end{array}$} & & & 5.12 & $* * *$ & -0.10 & & & & 3.11 & $* * *$ & -0.80 & & & & 8.03 & $* * *$ & 0.88 & \\
\hline & & & $(1.19)$ & & $(4.48)$ & & & & $(0.84)$ & & $(3.16)$ & & & & $(1.71)$ & & $(6.46)$ & \\
\hline \multirow[t]{2}{*}{$A * B$} & & & & & 1.12 & & & & & & -0.16 & & & & & & 2.33 & \\
\hline & & & & & $(1.98)$ & & & & & & $(1.42)$ & & & & & & $(2.83)$ & \\
\hline \multirow[t]{2}{*}{$\mathrm{B}^{*} \mathrm{C}$} & & & & & -2.03 & & & & & & 1.43 & & & & & & -1.12 & \\
\hline & & & & & $(2.22)$ & & & & & & $(1.56)$ & & & & & & $(3.16)$ & \\
\hline \multirow[t]{2}{*}{$\mathrm{A}^{*} \mathrm{C}$} & & & & & 4.35 & * & & & & & 0.69 & & & & & & 4.51 & + \\
\hline & & & & & $(1.92)$ & & & & & & $(1.32)$ & & & & & & $(2.72)$ & \\
\hline \multicolumn{19}{|l|}{ Control Variables: } \\
\hline \multirow[t]{2}{*}{ Unemployment rate } & -0.80 & & -0.86 & & -0.82 & & 1.37 & $* * *$ & 1.36 & $* * *$ & 1.36 & $* * *$ & 0.67 & & 0.64 & & 0.71 & \\
\hline & $(0.57)$ & & $(0.55)$ & & $(0.55)$ & & $(0.40)$ & & $(0.39)$ & & $(0.39)$ & & $(0.83)$ & & $(0.80)$ & & $(0.79)$ & \\
\hline \multirow[t]{2}{*}{ Telecommunications } & -4.91 & $* *$ & -3.67 & $*$ & -3.54 & * & 0.69 & & 1.40 & & 1.29 & & -3.24 & & -1.38 & & -1.25 & \\
\hline & $(1.62)$ & & $(1.64)$ & & $(1.64)$ & & $(1.17)$ & & $(1.19)$ & & $(1.20)$ & & $(2.40)$ & & $(2.40)$ & & $(2.41)$ & \\
\hline \multirow[t]{2}{*}{ Union represented } & -9.05 & $* * *$ & -8.59 & $* * *$ & -8.47 & $* * *$ & -4.01 & * & -3.47 & $*$ & -3.37 & + & -12.97 & $* * *$ & -12.03 & $* * *$ & -11.65 & $* * *$ \\
\hline & $(2.07)$ & & $(2.09)$ & & $(2.10)$ & & $(1.63)$ & & $(1.70)$ & & $(1.72)$ & & $(3.26)$ & & $(3.32)$ & & $(3.36)$ & \\
\hline \multirow[t]{2}{*}{ In-house center } & 0,04 & & 2.66 & & 2.67 & & -0.88 & & 0.80 & & 0.62 & & -0.77 & & 3.55 & & 3.62 & \\
\hline & $(2.34)$ & & $(2.15)$ & & $(2.16)$ & & $(1.66)$ & & $(1.56)$ & & $(1.58)$ & & $(3.45)$ & & $(3.20)$ & & $(3.22)$ & \\
\hline \multirow[t]{2}{*}{ Large business clients } & -2.92 & & -1.52 & & -1.45 & & 0.42 & & 1.44 & & 1.34 & & -2.45 & & -0.15 & & -0.24 & \\
\hline & $(2.16)$ & & $(2.17)$ & & $(2.17)$ & & $(1.59)$ & & $(1.63)$ & & $(1.63)$ & & $(3.23)$ & & $(3.20)$ & & $(3.20)$ & \\
\hline \multirow[t]{2}{*}{ Small business clients } & -5.32 & $*$ & -6.25 & $* *$ & -6.17 & $* *$ & -2.49 & & -2.93 & + & -3.08 & + & -7.76 & * & -9.44 & $* *$ & -9.25 & $* *$ \\
\hline & $(2.48)$ & & $(2.30)$ & & $(2.31)$ & & $(1.79)$ & & $(1.71)$ & & $(1.70)$ & & $(3.69)$ & & $(3.43)$ & & $(3.46)$ & \\
\hline Residential clients & -0.62 & & -1.44 & & -1.01 & & 0.37 & & -0.07 & & -0.09 & & -0.72 & & -1.95 & & -1.52 & \\
\hline & $(1.91)$ & & $(1.83)$ & & $(1.84)$ & & $(1.34)$ & & $(1.30)$ & & $(1.31)$ & & $(2.79)$ & & $(2.66)$ & & $(2.68)$ & \\
\hline Workforce size & 0.30 & & 0.19 & & 0.21 & & 0.02 & & -0.03 & & -0.03 & & 0.25 & & 0.09 & & 0.11 & \\
\hline
\end{tabular}




\begin{tabular}{|c|c|c|c|c|c|c|c|c|c|c|c|c|c|c|c|c|c|c|}
\hline \multirow{3}{*}{ Percent female } & $(0.20)$ & & $(0.20)$ & & $(0.20)$ & & $(0.14)$ & & $(0.14)$ & & $(0.14)$ & & $(0.30)$ & & $(0.29)$ & & $(0.29)$ & \\
\hline & 4.21 & & 4.04 & & 4.46 & & -3.21 & & -2.85 & & -2.93 & & 0.90 & & 0.62 & & 1.30 & \\
\hline & (3.81) & & (3.79) & & $(3.83)$ & & $(2.68)$ & & $(2.69)$ & & $(2.73)$ & & $(5.49)$ & & (5.41) & & $(5.47)$ & \\
\hline \multirow[t]{2}{*}{ Average education } & -1.09 & + & -0.12 & & -0.20 & & -1.72 & $* * *$ & -1.14 & $* *$ & -1.17 & $* *$ & -2.59 & $* *$ & -1.15 & & -1.23 & \\
\hline & $(0.56)$ & & $(0.57)$ & & $(0.57)$ & & $(0.41)$ & & $(0.42)$ & & $(0.42)$ & & $(0.83)$ & & $(0.82)$ & & $(0.83)$ & \\
\hline \multirow[t]{2}{*}{ Initial training } & -4.07 & + & -3.67 & + & -4.10 & * & -1.82 & & -1.56 & & -1.54 & & -5.88 & + & -5.33 & + & -5.71 & * \\
\hline & $(2.16)$ & & $(2.02)$ & & $(2.02)$ & & $(1.47)$ & & $(1.40)$ & & $(1.42)$ & & $(3.07)$ & & $(2.87)$ & & $(2.87)$ & \\
\hline \multirow[t]{2}{*}{ Selection ratio } & 8.04 & * & 4.54 & & 4.48 & & 6.94 & $* *$ & 5.01 & * & 5.10 & * & 14.93 & ** & 9.90 & * & 9.91 & $*$ \\
\hline & $(3.60)$ & & $(3.50)$ & & $(3.49)$ & & $(2.47)$ & & $(2.42)$ & & $(2.42)$ & & $(5.19)$ & & $(4.99)$ & & $(4.99)$ & \\
\hline \multirow[t]{2}{*}{ Systematic selection } & 0.97 & & -0.48 & & -0.33 & & 0.53 & & -0.28 & & -0.38 & & 0.96 & & -1.32 & & -1.26 & \\
\hline & $(1.67)$ & & (1.63) & & $(1.63)$ & & $(1.16)$ & & $(1.15)$ & & $(1.15)$ & & $(2.43)$ & & $(2.36)$ & & $(2.36)$ & \\
\hline \multirow[t]{2}{*}{ Age of establishment } & -0.04 & & 0.02 & & 0.01 & & -0.16 & $* * *$ & -0.13 & $* *$ & -0.13 & ** & -0.19 & * & -0.09 & & -0.11 & \\
\hline & $(0.06)$ & & $(0.06)$ & & $(0.06)$ & & $(0.04)$ & & $(0.04)$ & & $(0.04)$ & & $(0.09)$ & & $(0.08)$ & & $(0.08)$ & \\
\hline \multirow[t]{2}{*}{ Layoffs } & -0.60 & & 0.25 & & 0.48 & & 1.93 & & 2.49 & + & 2.60 & + & 1.84 & & 3.28 & & 3.59 & \\
\hline & (1.91) & & $(1.87)$ & & $(1.87)$ & & $(1.41)$ & & $(1.40)$ & & $(1.40)$ & & $(2.84)$ & & $(2.75)$ & & $(2.75)$ & \\
\hline \multirow[t]{2}{*}{ Constant } & 38.35 & $* *$ & 16.34 & & -0.42 & & 33.78 & $* * *$ & 19.19 & $*$ & 9.53 & & 64.87 & $* * *$ & 33,43 & * & 6.91 & \\
\hline & $(12.65)$ & & $(12.57)$ & & $(20.77)$ & & $(9.55)$ & & $(9.62)$ & & $(15.61)$ & & $(17.00)$ & & $(16.69)$ & & $(27.55)$ & \\
\hline Likelihood Ratio Chi2 & 66.90 & $* * *$ & 111.20 & $* * *$ & 116.50 & $* * *$ & 83.57 & $* * *$ & 115.09 & $* * *$ & 117.18 & $* * *$ & 124.65 & $* * *$ & 124.75 & $* * *$ & 71.13 & $* * *$ \\
\hline$-2 *$ Log Likelihood & 2541.83 & & 2497.52 & & 2492.23 & & 2257.50 & & 2227.98 & & 2225.89 & & 2069.47 & & 2809.67 & & 2863.28 & \\
\hline
\end{tabular}

Marginal effects reported; $\mathrm{N}=339 ;+=\mathrm{p}<.10 .^{*}=\mathrm{p}<.05 * *=\mathrm{p}<.01 . * * *=\mathrm{p}<.001$ 
TABLE 3

Longitudinal Analysis of Lagged HR Indexes on Quits, Dismissals, and Total Turnover (Tobit Models)

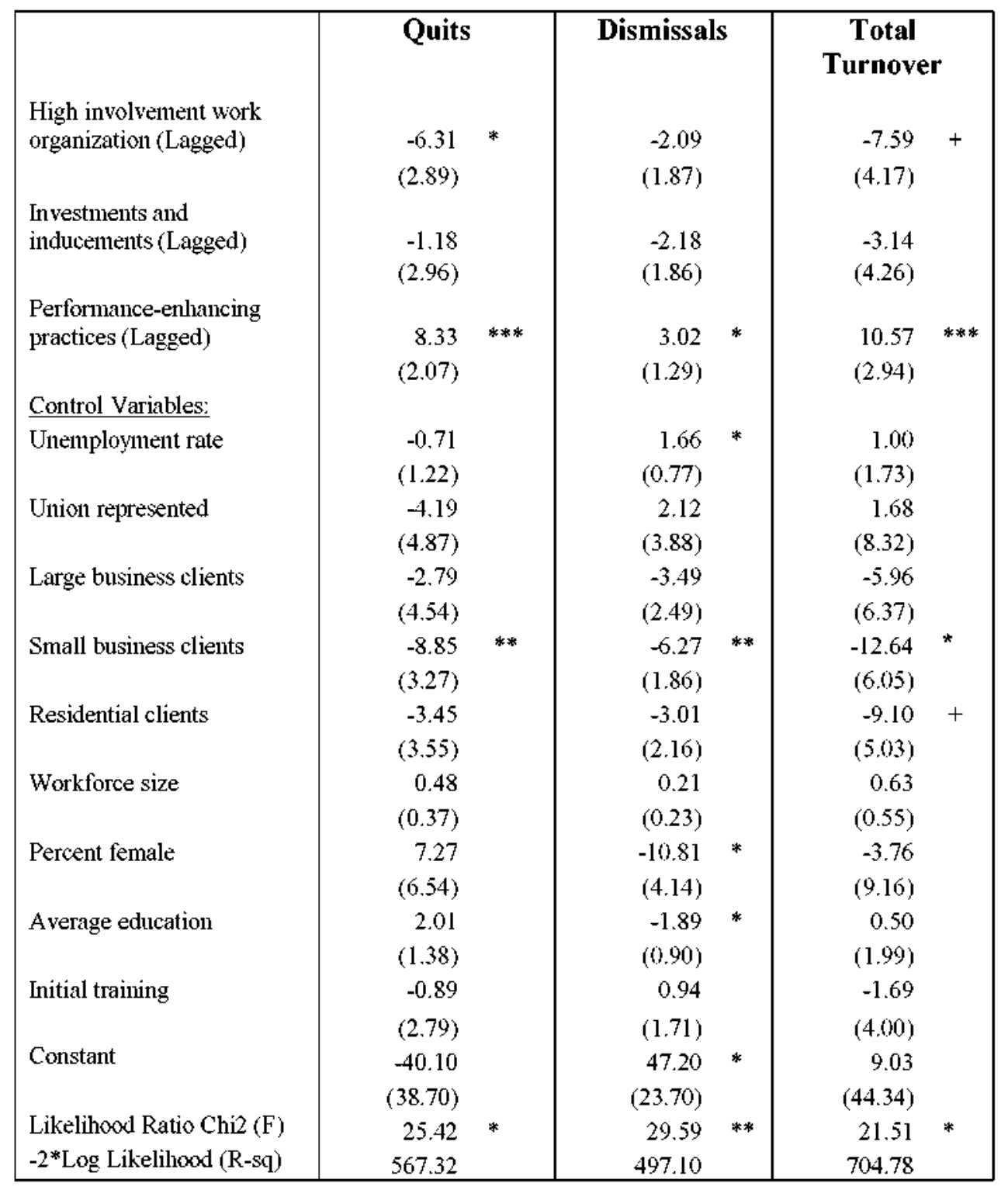

Marginal effects reported; $\mathrm{N}=93 ;+=\mathrm{p}<.10, *=\mathrm{p}<.05, * *=\mathrm{p}<.01, * * *=\mathrm{p}<.001$ 
TABLE 4

Customer Satisfaction as a Function of Work Organization,

Investments \& Inducements, Performance-enhancing Practices, and Turnover (OLS Models)

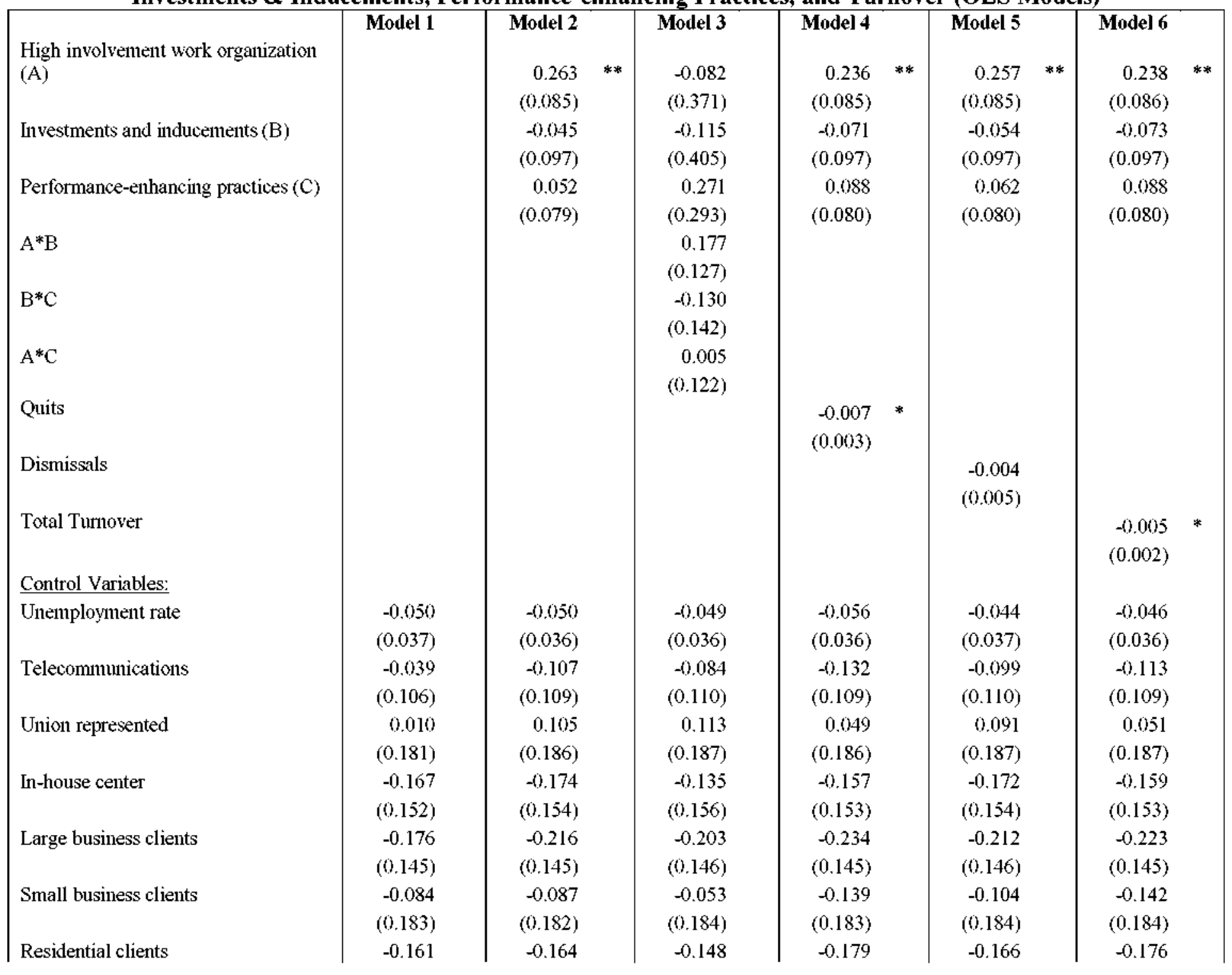




\begin{tabular}{|c|c|c|c|c|c|c|c|c|c|c|c|}
\hline & $(0.123)$ & $(0.123)$ & & $(0.124)$ & & $(0.122)$ & & $(0.123)$ & & $(0.122)$ & \\
\hline Workforce size & 0.014 & 0.018 & & 0.018 & & 0,020 & & 0.018 & & 0.019 & \\
\hline \multirow[b]{2}{*}{ Percent female } & $(0.013)$ & $(0.013)$ & & $(0.013)$ & & $(0.013)$ & & $(0.013)$ & & $(0.013)$ & \\
\hline & $\begin{array}{r}0.276 \\
(0.237)\end{array}$ & $\begin{array}{r}0.365 \\
(0.241)\end{array}$ & & $\begin{array}{r}0.433 \\
(0.245)\end{array}$ & + & $\begin{array}{r}0.386 \\
(0.240)\end{array}$ & & $\begin{array}{r}0.353 \\
(0.242)\end{array}$ & & $\begin{array}{r}0.363 \\
(0.240)\end{array}$ & \\
\hline \multirow[t]{2}{*}{ Average education } & $0.092 *$ & 0.073 & + & 0.075 & * & 0.071 & + & 0.070 & + & 0.067 & + \\
\hline & $(0036)$ & $(0038)$ & & $(0038)$ & & $(0.037)$ & & $(0038)$ & & $(0.038)$ & \\
\hline \multirow{2}{*}{ Initial training } & 0.139 & 0.128 & & 0.125 & & 0.100 & & 0.121 & & 0.101 & \\
\hline & $(0.128)$ & $(0.127)$ & & $(0.128)$ & & $(0.127)$ & & $(0.127)$ & & $(0.127)$ & \\
\hline Selection ratio & $\begin{array}{r}-0.450 \quad * \\
(0.227)\end{array}$ & $\begin{array}{r}-0.409 \\
(0.229)\end{array}$ & + & $\begin{array}{r}-0.419 \\
(0.229)\end{array}$ & + & $\begin{array}{r}-0.375 \\
(0.228)\end{array}$ & & $\begin{array}{r}-0.390 \\
(0.230)\end{array}$ & + & $\begin{array}{r}-0.363 \\
(0.229)\end{array}$ & \\
\hline \multirow[t]{2}{*}{ Systematic selection } & 0.124 & 0.141 & & 0.152 & & 0.134 & & 0.137 & & 0.131 & \\
\hline & $(0.107)$ & $(0.108)$ & & $(0.109)$ & & $(0.107)$ & & $(0.108)$ & & $(0.108)$ & \\
\hline \multirow[t]{2}{*}{ Age of establishment } & -0.002 & -0003 & & -0.003 & & -0.003 & & $-0,003$ & & -0.003 & \\
\hline & $(0.004)$ & $(0.004)$ & & $(0.004)$ & & $(0.004)$ & & $(0.004)$ & & $(0.004)$ & \\
\hline Layoffs & $\begin{array}{r}-0.134 \\
(0.123)\end{array}$ & $\begin{array}{r}-0.143 \\
(0.122)\end{array}$ & & $\begin{array}{r}-0.146 \\
(0.122)\end{array}$ & & $\begin{array}{r}-0.143 \\
(0.121)\end{array}$ & & $\begin{array}{c}-0.131 \\
(0.123)\end{array}$ & & $\begin{array}{r}-0.128 \\
(0.122)\end{array}$ & \\
\hline Constant & $\begin{array}{c}-0.839 \\
(0.626)\end{array}$ & $\begin{array}{r}-0.608 \\
(0.647)\end{array}$ & & $\begin{array}{c}-0.973 \\
(1.070)\end{array}$ & & $\begin{array}{c}-0.462 \\
(0.647)\end{array}$ & & $\begin{array}{c}-0.553 \\
(0.651)\end{array}$ & & $\begin{array}{r}-0.445 \\
(0.649)\end{array}$ & \\
\hline $\mathrm{F}$ & 1.25 & 1.61 & + & 1.52 & + & 1.79 & * & 1.55 & + & 1.74 & $*$ \\
\hline R-sq & 0.05 & 0.08 & $r$ & 0.09 & & 0.10 & & 0.08 & & 0.00 & \\
\hline
\end{tabular}

$\mathrm{N}=339 ;+=\mathrm{p}<.10, *=\mathrm{p}<.05, * *=\mathrm{p}<.01, * * *=\mathrm{p}<.001$ 


\section{Appendix 1: Variable Definitions}

\begin{tabular}{|c|c|}
\hline Quits & The percentage of workers who quit voluntarily in the past year, \\
\hline Dismissals & $\begin{array}{l}\text { The percentage of workers dismissed in the past year, not including workers who were laid-off, promoted, or } \\
\text { retired or quit voluntarily. }\end{array}$ \\
\hline Total turnover & The quit rate plus the dismissal rate. \\
\hline Customer satisfaction & $\begin{array}{l}\text { The mean of the responses to two standardized items (alpha }=0.59 \text { ): } \\
\text { - The average level of customer satisfaction (on a } 1-5 \text { scale); } \\
\text { - How the call center's level of customer satisfaction compares to other call centers it competes with (on a } \\
1 \text { to } 5 \text { scale, with anchors "much lower" and "much higher"). }\end{array}$ \\
\hline
\end{tabular}

Independent variables

Work organization and performance management

An index based on 3 items, standardized and averaged:

- Discretion: an 8-item index of discretion over tasks, tools, pace of work, breaks, work methods, what to say to customers, handling additional customer requests, handling customer complaints (each item was

High involvement

Work organization measured with a 1 to 5 Likert-scale type question with anchors "none" and "complete"; the mean response for the 8 questions was 2.87 ) (alpha $=0.77$ )

- Problem-solving groups: the average percent of workers in off-line problem-solving.

- Self-directed teams: the average percent of workers in on-line self-directed work groups.

An index based on 4 items, standardized and averaged:

- Internal mobility opportunities: the percentage of the core workforce promoted to higher positions at the worksite or promoted or transferred within the larger organization.

Investments and

Inducements

- Relative pay: ratio of the average annual pay (in $\$ 100,000$ 's) of the typical (median) core worker compared to the median wage of customer service employees (Occupation code 43-405I, OES survey) in the metropolitan area or county in which the establishment is located (BLS 2001).

- Pensions: whether employees are covered by a defined benefit pension plan ( 1 ) or not $(0)$.

- Employment security: Proportion of the workforce that is full-time and permanent.

An index based on 2 items, standardized and averaged:

- Monitoring intensity. An index based on 5 items, standardized and averaged (response anchors for Likert-type scale questions are in parentheses after the item): How often core employees receive feedback on their performance (never-continously); how often their calls are listened to by supervisors (rarely-every day); how often calls are monitored without their knowledge (never-always); how often they get feedback and coaching on phone technique (rarely-every day); and to what extent information from performance monitoring is used to support disciplinary actions (not at all-a very great extent) (Alpha $=.70$ ).

Performance-enhancing expectations

- Conmission pay: The proportion of annual pay based on individual commission.

Control Variables

Human capital, workforce quality and demographic characteristics

\begin{tabular}{|l|l|}
\hline Female workforce & The proportion of core employees who are women. \\
\hline Education level & Years of education of the typical core employee at the worksite. \\
\hline Initial training & $\begin{array}{l}\text { Number of weeks it takes for a full-time core employee to become fully competent on the job (E.g. able to } \\
\text { train someone else). }\end{array}$ \\
\hline Selection ratio & Proportion of applicants hired. \\
\hline $\begin{array}{l}\text { Systematic selection } \\
\text { procedures }\end{array}$ & $\begin{array}{l}\text { Proportion of core workforce hired using systematic selection procedures (such as psychometric tests or } \\
\text { aptitude tests). }\end{array}$ \\
\hline Market, Institutional, and organizational characteristics \\
\hline Unemployment rate & Local unemployment rate. \\
\hline Sector: Telecom & In-house center serving telecommunications (1= Telecommunications, else 0). \\
\hline Union coverage & Whether the call center is covered by collective bargaining for core employees. \\
\hline Customer segment: & $\begin{array}{l}\text { A series of indicators for the primary customer segment served: Large business, small business, residential, or } \\
\text { all (onnitted category) }\end{array}$ \\
\hline Ownership: In-house & $\begin{array}{l}\text { Whether the call center is an in-house operation providing services to clients of one company or is a sub- } \\
\text { contractor providing services to other companies. ( } 1 \text { = In-house; sub-contractor = 0). }\end{array}$ \\
\hline Size & Number of call center agents in the establishment (in 100's). \\
\hline Age of establishment & Number of years since establishment opened. \\
\hline
\end{tabular}


Appendix 2

Quits, Dismissals, and Customer Satisfaction as Functions of High Involvement Work Organization, Investments and Inducements, and Performance-enhancing Practices [Models Using Individual Practices instead of Indices]

\begin{tabular}{|c|c|c|c|c|c|c|c|c|c|c|}
\hline $\begin{array}{l}\text { High involvement work } \\
\text { organization: }\end{array}$ & $\begin{array}{r}\text { Quits } \\
\text { [Tobit] }\end{array}$ & & $\begin{array}{r}\text { Dismissals } \\
\text { [Tobit] }\end{array}$ & & $\begin{array}{r}\text { Total } \\
\text { Turnover } \\
\text { [Tobit] }\end{array}$ & & $\begin{array}{r}\text { Customer } \\
\text { Satisfaction } \\
\text { [OLS] }\end{array}$ & & $\begin{array}{l}\text { Customer } \\
\text { Satisfaction } \\
\text { [OLS] }\end{array}$ & \\
\hline Discretion & $\begin{array}{r}-3.31 \\
(1.27)\end{array}$ & $* *$ & $\begin{array}{r}-2.74 \\
(0.86)\end{array}$ & $* *$ & $\begin{array}{r}-5.98 \\
(1.80)\end{array}$ & $* *$ & $\begin{array}{r}0.185 \\
(0.081)\end{array}$ & $*$ & $\begin{array}{r}0.159 \\
(0.082)\end{array}$ & + \\
\hline Problem-solving groups & $\begin{array}{r}-0.07 \\
(0.02)\end{array}$ & $* *$ & $\begin{array}{r}-0.03 \\
(0.02)\end{array}$ & $*$ & $\begin{array}{r}-0.08 \\
(0.03)\end{array}$ & $*$ & $\begin{array}{r}0.003 \\
(0.002)\end{array}$ & * & $\begin{array}{r}0.003 \\
(0.002)\end{array}$ & * \\
\hline $\begin{array}{l}\text { Self-directed teams } \\
\text { Investments and } \\
\text { inducements: }\end{array}$ & $\begin{array}{r}-0.01 \\
(0.02)\end{array}$ & & $\begin{array}{r}0.02 \\
(0.02)\end{array}$ & & $\begin{array}{r}0.00 \\
(0.04)\end{array}$ & & $\begin{array}{r}0.002 \\
(0.002)\end{array}$ & & $\begin{array}{r}0.002 \\
(0.002)\end{array}$ & \\
\hline Internal mobility & $\begin{array}{r}-5.35 \\
(3.92)\end{array}$ & & $\begin{array}{r}-8.21 \\
(2.70)\end{array}$ & $* *$ & $\begin{array}{r}-14.30 \\
(5.57)\end{array}$ & $*$ & $\begin{array}{r}-0.108 \\
(0.252)\end{array}$ & & $\begin{array}{r}-0.177 \\
(0.254)\end{array}$ & \\
\hline Relative pay & $\begin{array}{r}4.10 \\
(7.20)\end{array}$ & & $\begin{array}{r}3.16 \\
(5.05)\end{array}$ & & $\begin{array}{r}8.24 \\
(10.29)\end{array}$ & & $\begin{array}{r}0.514 \\
(0.469)\end{array}$ & & $\begin{array}{r}0.545 \\
(0.468)\end{array}$ & \\
\hline Pensions & $\begin{array}{r}-1.40 \\
(1.62)\end{array}$ & & $\begin{array}{r}-2.22 \\
(1.11)\end{array}$ & * & $\begin{array}{r}-3.83 \\
(2.32)\end{array}$ & + & $\begin{array}{r}-0.063 \\
(0.107)\end{array}$ & & $\begin{array}{r}-0.079 \\
(0.107)\end{array}$ & \\
\hline Proportion full-time & $\begin{array}{r}-4.68 \\
(2.51)\end{array}$ & + & $\begin{array}{r}1.24 \\
(1.72)\end{array}$ & & $\begin{array}{r}-3.54 \\
(3.63)\end{array}$ & & $\begin{array}{r}-0.374 \\
(0.168)\end{array}$ & $*$ & $\begin{array}{r}-0.395 \\
(0.167)\end{array}$ & * \\
\hline $\begin{array}{l}\text { Performance-enhancing } \\
\text { practices: }\end{array}$ & & & & & & & & & & \\
\hline $\begin{array}{l}\text { Monitoring intensity } \\
\text { Commission pay }\end{array}$ & $\begin{array}{r}2.88 \\
(1.44) \\
13.65 \\
(3.97)\end{array}$ & $* * *$ & $\begin{array}{r}2.02 \\
(1.01) \\
6.76 \\
(2.66)\end{array}$ & * & $\begin{array}{r}4.76 \\
(2.07) \\
20.72 \\
(5.57)\end{array}$ & $*$ & $\begin{array}{r}0.123 \\
(0.095) \\
-0.177 \\
(0.258)\end{array}$ & & $\begin{array}{r}0.142 \\
(0.095) \\
-0.084 \\
(0.262)\end{array}$ & \\
\hline Total turnover & & & & & & & & & $\begin{array}{r}-0.004 \\
(0.002)\end{array}$ & + \\
\hline$\frac{\text { Control Variables: }}{\text { Unemployment rate }}$ & $\begin{array}{r}-0.89 \\
(0.57)\end{array}$ & & $\begin{array}{r}1.04 \\
(0.40)\end{array}$ & $* *$ & $\begin{array}{r}0.26 \\
(0.83)\end{array}$ & & $\begin{array}{r}-0.035 \\
(0.038)\end{array}$ & & $\begin{array}{r}-0.033 \\
(0.038)\end{array}$ & \\
\hline
\end{tabular}




\begin{tabular}{|c|c|c|c|c|c|c|c|c|c|c|}
\hline Telecommunications & $\begin{array}{r}-4.06 \\
(1.87)\end{array}$ & $*$ & $\begin{array}{r}0.92 \\
(1.33)\end{array}$ & & $\begin{array}{c}-2.12 \\
(2.72)\end{array}$ & & $\begin{array}{r}-0.029 \\
(0.124)\end{array}$ & & $\begin{array}{r}-0.037 \\
(0.124)\end{array}$ & \\
\hline Union represented & -8.77 & $* *$ & $\begin{array}{r}-2.37 \\
187\end{array}$ & & -11.18 & $* *$ & $\begin{array}{r}0.133 \\
(0196)\end{array}$ & & $\begin{array}{r}0.083 \\
(0.197)\end{array}$ & \\
\hline In-house center & $\begin{array}{r}(2.18) \\
2.77 \\
(2.25)\end{array}$ & & $\begin{array}{r}(1.87) \\
1.15 \\
(1.59)\end{array}$ & & $\begin{array}{r}(3.56) \\
4.02 \\
(3.35)\end{array}$ & & $\begin{array}{r}(0.196) \\
-0.146 \\
(0.163)\end{array}$ & & $\begin{array}{r}(0.197) \\
-0.130 \\
(0.163)\end{array}$ & \\
\hline Large business clients & $\begin{array}{r}-2.80 \\
(2.36)\end{array}$ & & $\begin{array}{r}1.07 \\
(1.75)\end{array}$ & & $\begin{array}{r}-1.69 \\
(3.48)\end{array}$ & & $\begin{array}{r}-0.239 \\
(0.160)\end{array}$ & & $\begin{array}{c}-0.252 \\
(0.160)\end{array}$ & \\
\hline Small business clients & $\begin{array}{r}-6.64 \\
(2.35)\end{array}$ & $* *$ & $\begin{array}{r}-3.56 \\
(1.66)\end{array}$ & * & $\begin{array}{r}-10.48 \\
(3.45)\end{array}$ & ** & $\begin{array}{r}-0.060 \\
(0.188)\end{array}$ & & $\begin{array}{r}-0.118 \\
(0.190)\end{array}$ & \\
\hline Residential clients & $\begin{array}{r}-1.79 \\
(1.94)\end{array}$ & & $\begin{array}{r}0.03 \\
(1.36)\end{array}$ & & $\begin{array}{r}-2.35 \\
(2.82)\end{array}$ & & $\begin{array}{r}-0.193 \\
(0.131)\end{array}$ & & $\begin{array}{r}-0.205 \\
(0.131)\end{array}$ & \\
\hline Workforce size & $\begin{array}{r}0.17 \\
(0.20)\end{array}$ & & $\begin{array}{r}-0.00 \\
(0.14)\end{array}$ & & $\begin{array}{r}0.11 \\
(0.30)\end{array}$ & & $\begin{array}{r}0.018 \\
(0.014)\end{array}$ & & $\begin{array}{r}0.019 \\
(0.014)\end{array}$ & \\
\hline Percent female & $\begin{array}{r}5.91 \\
(3.97)\end{array}$ & & $\begin{array}{r}-3.16 \\
(2.77)\end{array}$ & & $\begin{array}{r}2.45 \\
(5.66)\end{array}$ & & $\begin{array}{r}0.421 \\
(0.253)\end{array}$ & + & $\begin{array}{r}0.425 \\
(0.252)\end{array}$ & + \\
\hline Average education & $\begin{array}{r}-0.45 \\
(0.61)\end{array}$ & & $\begin{array}{r}-1.22 \\
(0.44)\end{array}$ & $* *$ & $\begin{array}{r}-1.52 \\
(0.88)\end{array}$ & + & $\begin{array}{r}0.079 \\
(0.040)\end{array}$ & * & $\begin{array}{r}0.072 \\
(0.040)\end{array}$ & + \\
\hline Initial training & $\begin{array}{r}-5.45 \\
(2.36)\end{array}$ & $*$ & $\begin{array}{r}-1.51 \\
(1.59)\end{array}$ & & $\begin{array}{r}-6.79 \\
(3.27)\end{array}$ & * & $\begin{array}{r}0.125 \\
(0.143)\end{array}$ & & $\begin{array}{r}0.095 \\
(0.144)\end{array}$ & \\
\hline Selection ratio & $\begin{array}{r}5.16 \\
(3.61)\end{array}$ & & $\begin{array}{r}5.05 \\
(2.46)\end{array}$ & * & $\begin{array}{r}10.81 \\
(5.17)\end{array}$ & * & $\begin{array}{r}-0.399 \\
(0.239)\end{array}$ & + & $\begin{array}{r}-0.350 \\
(0.239)\end{array}$ & \\
\hline Systematic selection & $\begin{array}{r}-0.65 \\
(1.72)\end{array}$ & & $\begin{array}{r}-0.19 \\
(1.18)\end{array}$ & & $\begin{array}{r}-1.17 \\
(2.48)\end{array}$ & & $\begin{array}{r}0.129 \\
(0.114)\end{array}$ & & $\begin{array}{r}0.119 \\
(0.114)\end{array}$ & \\
\hline Age of establishment & $\begin{array}{r}0.04 \\
(0.06)\end{array}$ & & $\begin{array}{r}-0.15 \\
(0.04)\end{array}$ & $* * *$ & $\begin{array}{r}-0.09 \\
(0.09)\end{array}$ & & $\begin{array}{r}-0.003 \\
(0.004)\end{array}$ & & $\begin{array}{r}-0.004 \\
(0.004)\end{array}$ & \\
\hline Layotts & $\begin{array}{r}0.73 \\
(1.98)\end{array}$ & & $\begin{array}{r}2.87 \\
(1.45)\end{array}$ & * & $\begin{array}{r}3.81 \\
(2.89)\end{array}$ & & $\begin{array}{r}-0.220 \\
(0.129)\end{array}$ & + & $\begin{array}{r}-0.204 \\
(0.129)\end{array}$ & \\
\hline Constant & $\begin{array}{r}42.34 \\
(12.92)\end{array}$ & $* *$ & $\begin{array}{r}35.81 \\
(9.64)\end{array}$ & $* * *$ & $\begin{array}{r}70.03 \\
(17.03)\end{array}$ & $* * *$ & $\begin{array}{r}-1.318 \\
(0.673)\end{array}$ & + & $\begin{array}{r}-1.019 \\
(0.690)\end{array}$ & \\
\hline $\begin{array}{l}\text { Chi2 [F] } \\
-2^{*} \log \text { Likelihood [R-sq] } \\
\text { Obs }\end{array}$ & $\begin{array}{r}123.7 \\
2337.0 \\
321\end{array}$ & $* * *$ & $\begin{array}{r}127.6 \\
2052.0 \\
316\end{array}$ & $* * *$ & $\begin{array}{r}131.3 \\
2602.0 \\
316\end{array}$ & $* * *$ & $\begin{array}{r}{[1.63]} \\
{[0.12]} \\
316\end{array}$ & * & $\begin{array}{r}{[1.71]} \\
{[0.13]} \\
316\end{array}$ & $*$ \\
\hline
\end{tabular}

Marginal effects reported for tobit models: $+=p<.10 *=p<.05, * *=p<.01, * * *=p<.001$ 


\section{Author Bios}

Rosemary Batt (rb41@cornell.edu) is the Alice Hanson Cook Professor of Women and Work at the ILR School, Cornell University. She received her Ph.D. from the Sloan School of Management, Massachusetts Institute of Technology. Her research focuses on strategic HR management, employment relations, and organizational outcomes for firms and employees, particularly in service industries and cross-nationally.

Alexander J.S. Colvin (ajc22@cornell.edu) is Associate Professor of Labor Relations and Conflict Resolution at the ILR School, Cornell University. He received his Ph.D. from Cornell University. His research focuses on employment relations, dispute resolution, and the impact of the legal environment on organizations. 